\title{
Renewable energy homes for marine life: Habitat potential of a tidal energy project for benthic megafauna
}

\author{
Taormina Bastien 1, 2, ", Laurans Martial ${ }^{3}$, Marzloff Martin 2, Dufournaud Noémie ${ }^{3}$, Lejart Morgane 1,
} Desroy Nicolas ${ }^{4}$, Leroy Didier ${ }^{3}$, Martin Stephane ${ }^{3}$, Carlier Antoine ${ }^{2}$

\author{
${ }_{1}^{1}$ France Energies Marines, 525 Avenue Alexis de Rochon, 29280, Plouzané, France \\ 2 Ifremer, Centre de Bretagne, DYNECO - Laboratoire D'écologie Benthique, ZI de La Pointe Du Diable \\ - CS 10070, 29280, Plouzané, France \\ 3 Ifremer, Centre de Bretagne, Laboratoire Ressources Halieutiques, ZI de La Pointe Du Diable - CS \\ 10070, 29280, Plouzané, France \\ 4 Ifremer, Laboratoire Environnement Ressources Bretagne Nord, 38 Rue Du Port Blanc, 35801, \\ Dinard, France \\ * Corresponding author : Bastien Taormina, email address : bastien.taormina@france-energies- \\ marines.org
}

\begin{abstract}
:
An increasing number of offshore structures are being deployed worldwide to meet the growing demand for renewable energy. Besides energy production, these structures can also provide new artificial habitats to a diversity of fish and crustacean species. This study characterises how concrete mattresses that stabilise the submarine power cable of a tidal energy test site can increase habitat capacity for benthic megafauna. A five-year monitoring, which relied on both visual counts and video-based surveys by divers, revealed that these mattresses provide a suitable habitat for 5 taxa of large crustaceans and fish. In particular, two commercially valuable species, i.e. the edible crab Cancer pagurus and the European lobster Homarus gammarus, showed a constant occupancy of these artificial habitats throughout the course of the project. The shape and the number of shelters available below individual mattresses largely determine potential for colonisation by mobile megafauna. Local physical characteristics of the implantation site (e.g. substratum type, topography, exposition to current etc.) significantly impact amount and type of shelters provided by the concrete mattresses. Thus, to characterise habitat potential of artificial structures, it is not only essential to consider (i) the design of the structures, but also to (ii) account for their interactions with local environmental conditions when deployed on the seafloor.
\end{abstract}

\section{Highlights}

- The colonisation of artificial structures by benthic megafauna was surveyed during 5 years. Target taxa showed a constant occupancy of the artificial structures. Shape and number of shelters largely determine potential for colonisation. Local physical characteristics significantly impact amount and type of shelters. It is essential to consider both design of structures and interactions with environment.

Keywords : Artificial habitats, Marine renewable energy, Crustacean, Fish, Habitat 


\section{Abbreviations}

40 MRE, Marine Renewable Energy; GLMM, generalised linear mixed models; LMM, linear mixed

41 models; PCA, principal component analysis; RDA, redundancy analysis 


\section{INTRODUCTION}

Artificial reefs are man-made structures placed on the sea bed in aquatic habitats for different purposes, for instance to mimic characteristics of natural reefs such as substrate and/or shelter provision to associated organisms (Bohnsack et al., 1991; Jensen et al., 2000a; Thierry, 1988). Development of artificial reefs may locally increase both hard substratum availability and habitat heterogeneity (especially when deployed on soft-sediment bottoms), which can consequently lead to higher densities and biomass of fish and decapods (Bohnsack et al., 1994; Bombace et al., 1994; Langhamer and Wilhelmsson, 2009).

Enhancement of associated benthic diversity by artificial reefs depends both on reef properties and on local environmental characteristics. Colonisation success depends on artificial reef shape and size, constitutive material, orientation and degree of complexity, that directly determine habitat, and refuge availability (Charbonnel et al., 2002; Ferreira and Coutinho, 2001; Hackradt et al., 2011; Sherman et al., 2002). A range of local environmental factors (e.g. neighbouring habitat type, hydrological features, amplitude of seasonal variation) can significantly influence the amount and the diversity of colonising organisms (Bohnsack et al., 1991; Bombace et al., 1994; Godoy et al., 2002; Noh et al., 2017). A long-standing scientific debate persists between two dominant theories regarding the role of artificial reefs for mobile fauna: (i) the "attraction hypothesis" and (ii) the "production hypothesis" (Lima et al., 2019). The first assumes that artificial reefs only attract specimens from nearby ecological communities, without increasing overall biomass production (Bohnsack, 1989) while the latter advocates that artificial reefs increase abundance and biomass of associated species by enhancing habitat and food availability (Pickering and Whitmarsh, 1997; Polovina and Sakai, 1989). Literature shows that the two processes exist, the productive potential of artificial reef is indeed reefdependant and varies according to an important number of factors (e.g. number and design of reef units, distance to natural reef, association with protected area etc. ; Pickering and Whitmarsh, 1997). Nevertheless, Lima et al. (2019) highlight that, despite several decades of scientific observations and experiments on the subject, separating the reef effect and the effects of changing environmental and socioeconomic conditions remains complex, impacting the assessment of artificial reefs performance. 
Artificial reefs can be divided into two types: $i$ ) structures designed and installed specifically

for their reef properties (for a variety of reasons e.g. ecosystems conservation/restoration, fish stocks enhancement, fisheries management etc.; Jensen, 2002) and ii) structures deployed for other purposes, such as oil platforms, breakwaters, or marine renewable energy (MRE) facilities (Langhamer, 2012; Lima et al., 2019; Wilson and Elliott, 2009). MRE facilities and associated structures (e.g. protection structures, submarine power cables, foundations, turbines etc.) are not only colonised by a variety of benthic organisms including algae, sessile epifauna and mobile macrofauna but also mobile megafauna (i.e. fish and decapods). A diversity of fish and large crustaceans can settle on artificial reefs deployed as part of MRE facilities (see Wilhelmsson and Langhamer, 2014 for a review). For example, commercially valuable crustacean species such as the European lobster (Homarus gammarus) or the edible crab (Cancer pagurus) can shelter around the foundations of offshore wind (Hooper and Austen, 2014; Krone et al., 2017) or wave farms (Langhamer and Wilhelmsson, 2009). Thus, such reef effects can represent an ecological benefit of MRE, since artificial structures generally host higher diversity, densities and biomass of benthic organisms than the surrounding soft bottoms (Broadhurst and Orme, 2014; Dannheim et al., 2020; Langhamer and Wilhelmsson, 2009). Wilson and Elliott (2009) estimated that in the long term, a wind-turbine facility provides 2.5 times the amount of habitat relative to the initial loss during the installation process, even though this new habitat may be of a different character to the initial one. When their deployment requires the implementation of new exclusion areas for fishing, MRE may thus act as a refuge for commercially-exploited populations, with potential spill-over benefits for adjacent stocks and fisheries (Lindeboom et al., 2015, 2011). However, the long-term reef effect associated with MRE facilities remains poorly characterised (Copping et al., 2016; Langhamer and Wilhelmsson, 2009; Lindeboom et al., 2015), especially within high hydrodynamic energy areas (as tidal energy sites; Copping et al., 2016).

The purpose of this study is to assess the role of habitat associated with MRE facilities using a French tidal energy test site as a case study. We specifically examined the habitat capacity of concrete mattresses that stabilise an unburied submarine power cable that connects the test site to the mainland. Based on a 4-year monitoring of fish and crustacean abundance on these mattresses, we (1) characterise the reef effect associated with MRE structures, and more specifically (2) how interactions 
98 between artificial reefs and natural seafloor characteristics can determine diversity and abundance of 99 associated megafauna. 


\section{Journal Pre-proof}

\section{METHODS}

\subsection{Study site}

The study area consists of a $15 \mathrm{~km}-$ long submarine power cable (8 MVA - $10 \mathrm{kVDC}$ ) laid in 2012 by Electricité de France (EDF) to connect the tidal test site of Paimpol-Bréhat to the mainland (Brittany, France; Figure 1). Due to several setbacks in the project development, no electric current transited through the cable during the course of this study. An $11 \mathrm{~km}$ cable portion is unburied due to local seafloor characteristics (dominance of pebbles and presence of boulders; Figure 2.A) and stabilised by 120 concrete mattresses to prevent any cable displacement due to high hydrodynamic conditions. These mattresses are installed at depths ranging from 15 to $33 \mathrm{~m}$ and for the majority approximately $50 \mathrm{~m}$ apart (with some $200 \mathrm{~m}$ apart). The $6 \mathrm{~m}$-long, $3 \mathrm{~m}$-wide and $0.3 \mathrm{~m}$-thick mattresses are made up of 73 concrete blocks linked together by an array of polypropylene rope, and a

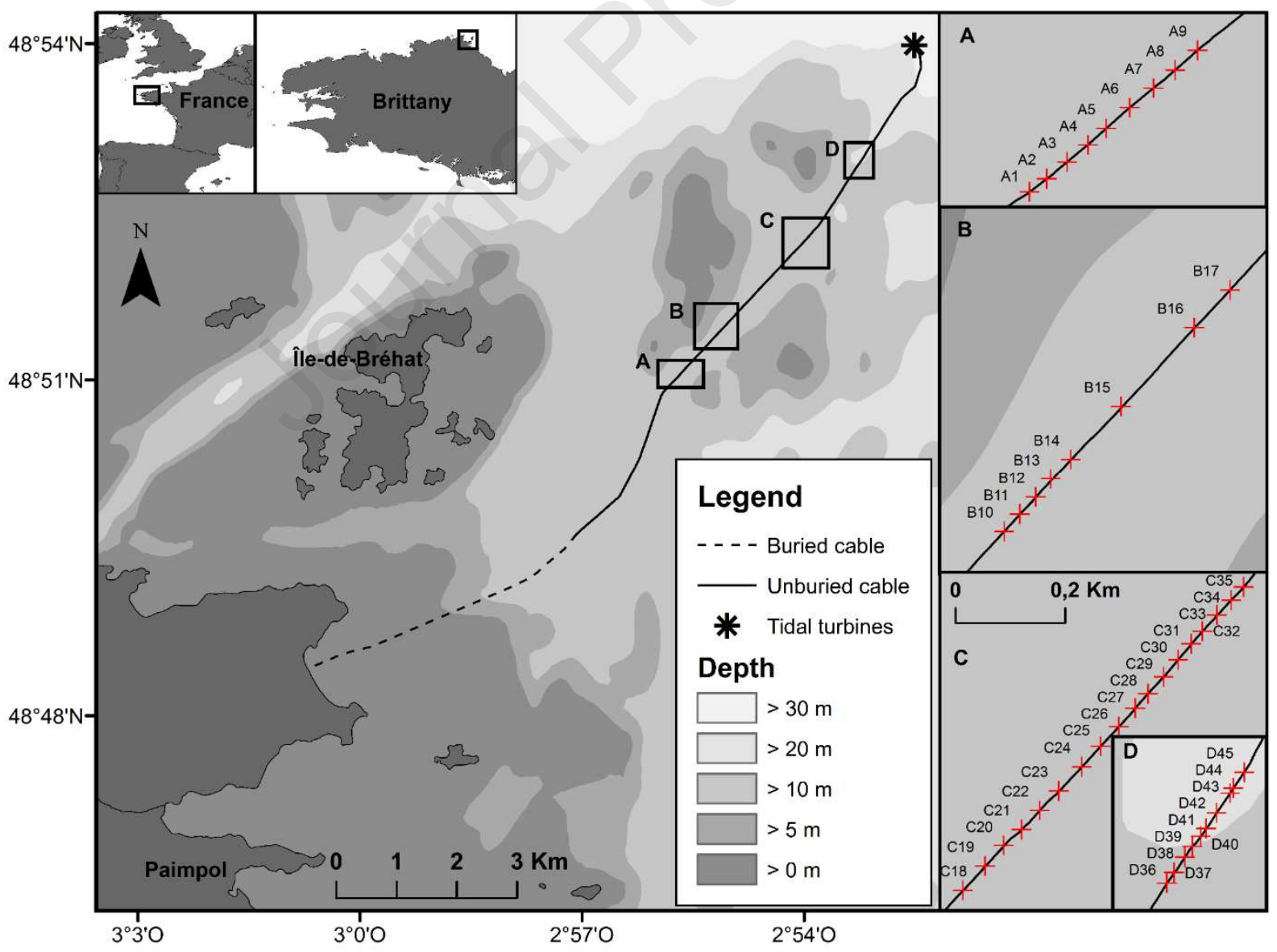

Figure 1: Map of the study area off the north coast of Brittany in Western France (top-left and topcentre panels). The thick black line represents the power cable that connects the Paimpol-Bréhat tidal test site to the mainland. Zones $A, B, C$ and $D$ (right) correspond to the four sites where concrete mattresses were surveyed. 
weight of $\sim 10 \mathrm{t}$.

\subsection{Target species}

A set of 5 benthic megafauna taxa easily recognisable by scuba-diving were surveyed: the crustaceans Homarus gammarus (European lobster) and Cancer pagurus (edible crab) and the benthic or demersal fish, Conger conger (European conger), Labrus bergylta (Ballan wrasse), and two species of the genus Trisopterus: T. luscus (whiting pout) and T. minutus (poor cod). These two latter species were hereafter gathered as a single taxon (Trisopterus spp.) since we cannot exclude that confusions of identification may have occurred.

\subsection{Sampling strategy}

Between June 2015 and September 2019, 45 different concrete mattresses in the 16-20 m depth range were surveyed by divers within four different zones along the cable (Zones A, B, C and D; Figure 1). These selected zones are located within a channel surrounded by several rocky shelves. A total of 45 mattresses were surveyed in June 2015, 30 in September 2015 (zone A, D and part of the zone C), 37 in June 2016 and 2017 (zone A, C and D); and only 20 in September 2019 (zone A and C Table 1). All surveys were performed at slack tides of neap tides and during daytime hours, i.e. between 8 am and $8 \mathrm{pm}$. During each survey, two divers inspected each mattress: the first diver moved slowly along the entire perimeter of the mattress while examining all the cavities and counting all conspicuous individuals of the 5 target species. Simultaneously, the second diver followed the first one around the mattress and recorded a video using a GoPro Hero $4^{\circledR}$ camera to provide some additional observations of the mobile fauna and the environment (substratum bottom type, frequency and forms of cavities etc.). Hereafter, a "sample" refers to all these pieces of information recorded for a given mattress, during a given campaign. 


\section{Journal Pre-proof}

133

\begin{tabular}{lll} 
Campaign & $\begin{array}{l}\text { Number of } \\
\text { Mattresses }\end{array}$ & Zone \\
\hline June 2015 & 45 & $\begin{array}{l}\text { A-B-C-D } \\
\text { A-C(only C25 } \\
\text { to C35)-D }\end{array}$ \\
September 2015 & 30 & $\begin{array}{l}\text { A-C-D } \\
\text { June 2016 }\end{array}$ \\
June 2017 & 37 & A-C-D \\
September 2019 & 20 & $\begin{array}{l}\text { A-C(only C25 } \\
\text { to C35) }\end{array}$
\end{tabular}

134

Table 1: Summary of the concrete mattresses and zones surveyed during each campaign.

135 


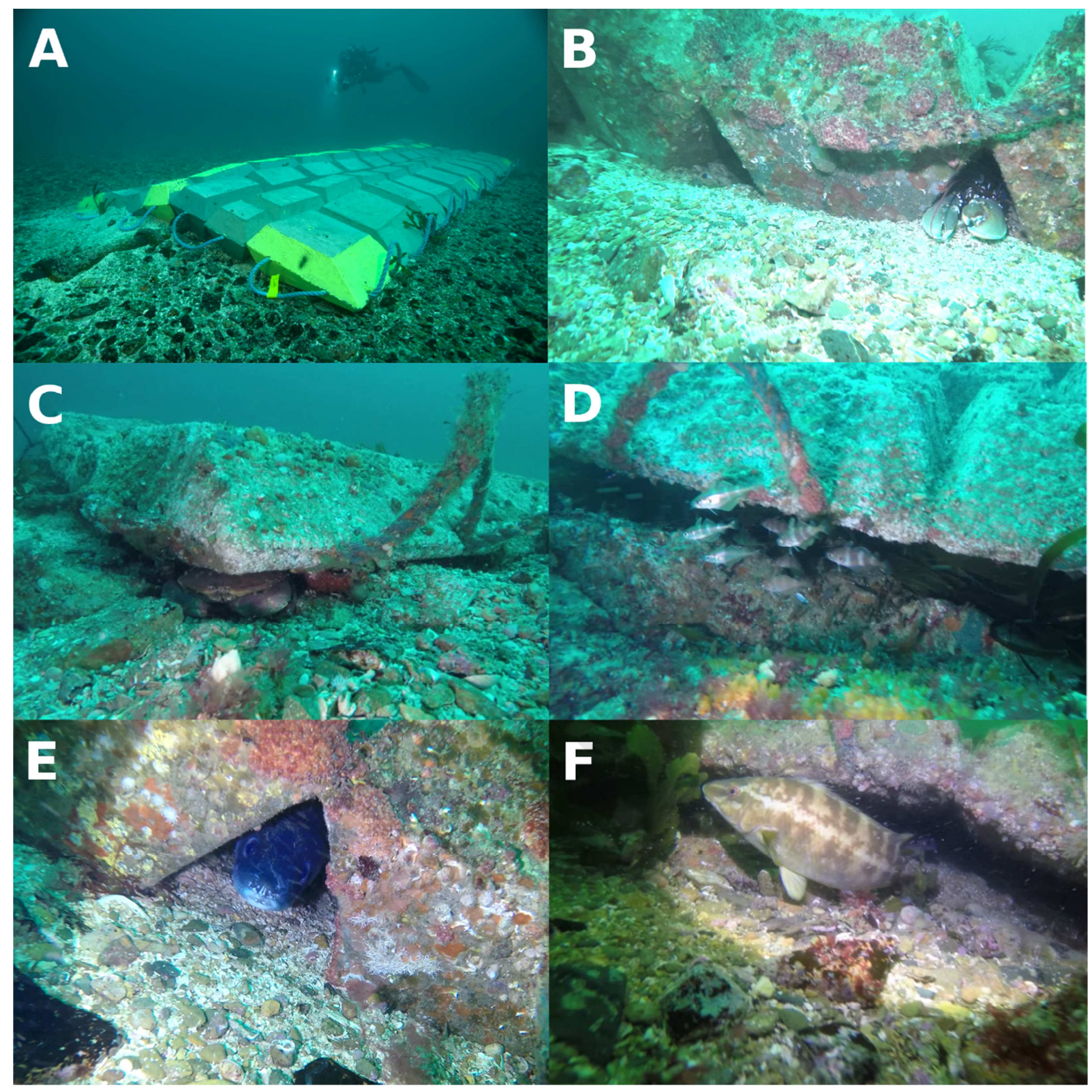

Figure 2: (A) Overall view of a concrete mattress (constituted of 73 concrete blocks) a few weeks after its installation on the power cable of the Paimpol-Bréhat tidal test site; (B) Homarus gammarus within a "hole", i.e. a small $20 \mathrm{~cm}$-wide triangular cavity between two concrete blocks; (C) Cancer pagurus within a "cave", i.e. a >10 cm high cavity formed below the mattress; (D) school of Trisopterus spp. close to a mattress "cave"; (E) Conger conger within a "hole" ; (F) Labrus bergylta close to a mattress "cave'.

\subsection{Environmental variables}

Substratum as well as types and number of cavities associated with each mattress were estimated one of three substratum categories: sand, pebbles or boulders. For each mattress, substratum properties 
were estimated as a proportion of these three categories across all peripheral concrete blocks (Table 2).

Two different types of cavity that can provide habitats to mobile fauna underneath the mattresses were identified: "holes", which correspond to small $\sim 20 \mathrm{~cm}$-wide triangular cavities between two concrete blocks along the mattress width (Figure 2.B \& E; Table 2); and "caves", which correspond to larger cavities formed below the mattress when it overhangs at least $10 \mathrm{~cm}$ above the seafloor (Figure 2.C, D \& F; Table 2).

In addition, the following environmental variables were extracted for each mattress (Table 2): (1) bottom residual current velocity (computed from a 2010-2015 climatology extracted from the MANGA500-MARS3D hydrodynamic model); (2) seafloor facet exposure to residual current (computed using seafloor aspect and residual current direction and ranging from $0^{\circ}$, when the seafloor is sheltered, to $180^{\circ}$, when it is fully exposed to dominant current) and (3) linear distances from each mattress to the closest $5 \mathrm{~m}$ and $10 \mathrm{~m}$ depth isobaths. This final shortlist of environmental variables was defined by removing correlated variables $(>0.7)$ from an original selection that only included wellresolved biologically-relevant parameters.

\subsection{Biological data}

In addition to in situ abundance counts performed by divers, video counts of all visible individuals were performed for the same 5 target species (Table 2). To avoid multiple counts of single individuals of Trisopterus spp. given their high mobility, the maximum number of individuals occurring in a single snapshot of the full video was recorded. In order to investigate species-specific sheltering preferences, the positions of each counted individual with respect to the mattress was noted as either $i$ ) inside a "hole", ii) inside a "cave", or iii) free-moving outside any cavities.

For H. gammarus, C. pagurus and C. conger, we used in situ counts performed by divers for multivariate analyses (Table 2), since video counts underestimated the abundance of these three species (SI 1) due to their cryptic behaviours. For the 2 other target taxa L. bergylta and Trisopterus spp., we used video counts for multivariate analyses (Table 2) since in situ counts were less accurate due to the high mobility of these species and the tendency to form dense schools of Trisopterus spp. 
167 (SI 1). All video analyses were performed using the Ifremer ADELIE ${ }^{\Theta}$ Software V2.0 according to the 168 methodology developed and tested by Dufournaud (2018).

\begin{tabular}{|c|c|c|c|c|c|c|}
\hline & Variable & Unit & Origin & Mean & Min & Max \\
\hline \multirow{5}{*}{$\begin{array}{l}\frac{\pi}{\tilde{J}} \\
\frac{\pi}{0} \\
\frac{0}{60} \\
\frac{0}{0} \\
\frac{0}{0}\end{array}$} & Homarus gammarus & count & in situ & 1.1 & 0 & 5 \\
\hline & Cancer pagurus & count & in situ & 1.5 & 0 & 5 \\
\hline & Conger conger & count & in situ & 1.4 & 0 & 4 \\
\hline & Trisopterus spp. & count & video & 3.5 & 0 & 68 \\
\hline & Labrus bergylta & count & video & 1.1 & 0 & 6 \\
\hline \multirow{9}{*}{ 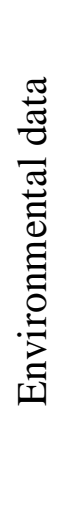 } & Sand proportion & $\%$ & video & $67 \%$ & $0 \%$ & $100 \%$ \\
\hline & Pebble proportion & $\%$ & video & $27 \%$ & $0 \%$ & $100 \%$ \\
\hline & Boulder proportion & $\%$ & video & $6 \%$ & $0 \%$ & $89 \%$ \\
\hline & Number of holes & count & video & 10.2 & 3 & 12 \\
\hline & Number of caves & count & video & 9.2 & 0 & 28 \\
\hline & Bottom-current velocity & $\mathrm{m} \mathrm{s}^{-1}$ & GIS & 0.71 & 0.65 & 0.99 \\
\hline & Exposure & $\circ$ & GIS & 93.8 & 12.7 & 163.8 \\
\hline & Distance to $5 \mathrm{~m}$ isobath & $\mathrm{m}$ & GIS & 500.2 & 149.7 & 791.2 \\
\hline & Distance to $10 \mathrm{~m}$ isobath & $\mathrm{m}$ & GIS & 245.1 & 62 & 403.5 \\
\hline
\end{tabular}

169

Table 2: Summary of all biological and environmental variables considered in this study, either measured in situ or from video footage, or derived from bathymetric map or from the MARS3D hydrodynamic model.

Due to poor footage quality, only 129 out of the 169 videos could be fully analysed and were used to perform multivariate analyses. To investigate specific habitat preferences, we also reported the type of cavity (either inside a "hole", inside a "cave", or free-moving out of any cavities) where each specimen was detected on the 129 videos.

\subsection{Data analysis}

Three main types of statistical analyses were performed, namely: $i$ ) generalised linear mixed models (GLMM) and linear mixed models (LMM) to explore temporal variations in megafauna abundance and diversity, ii) a principal component analysis (PCA) to study patterns in megafauna assemblage compositions, and iii) a redundancy analysis (RDA) to examine how variability in megafauna community relates to environmental conditions. 
Using count data available for each mattress surveyed during the five campaigns, (i) GLMMs

were applied to study temporal variations in the abundance per mattress of each target species and the total community abundance across all species (with and without Trisopterus spp.) per mattress; and (ii) a LMM was apply to study temporal variation in species richness per mattress. As count estimates correspond to repeated measures through time, mattress identity was treated as a random effect and campaign date was the only categorical explanatory variable included in all models to assess temporal variation. Each GLMM was fitted assuming either a Poisson distribution (for abundances of $H$. gammarus and $C$. conger), or a negative-binomial distribution when residuals with the former were overdispersed (for abundances of C. pagurus, L. bergylta, Trisopterus spp. and total community abundance with and without Trisopterus spp.). For each model, significance of the factor "campaign" was then assessed with Chi-Squared tests for GLMMs and F-test for LMM. When appropriate, a posthoc test using Tukey correction was performed to study pairwise differences between campaigns. We then characterised variability in megafauna composition between samples using a PCA. Finally, to relate community variability to changes in environmental variables (Table 2), we performed a Redundancy Analysis (RDA; (Legendre and Legendre, 1998)). Using a Monte-Carlo permutation test (999 permutations), a forward selection process was performed to identify environmental variables that best correlate to observed variability in community composition. In order to reduce the weight of abundant school-forming species such as Trisopterus spp., a logarithmic transformation was applied to the abundance data set before all multivariate analyses. Environmental variables were normalised prior to RDA analysis. Data analysis was performed with Rstudio (RStudio Team, 2015) using the vegan (Oksanen et al., 2018) and ggplot2 (Wickham, 2016) packages. 

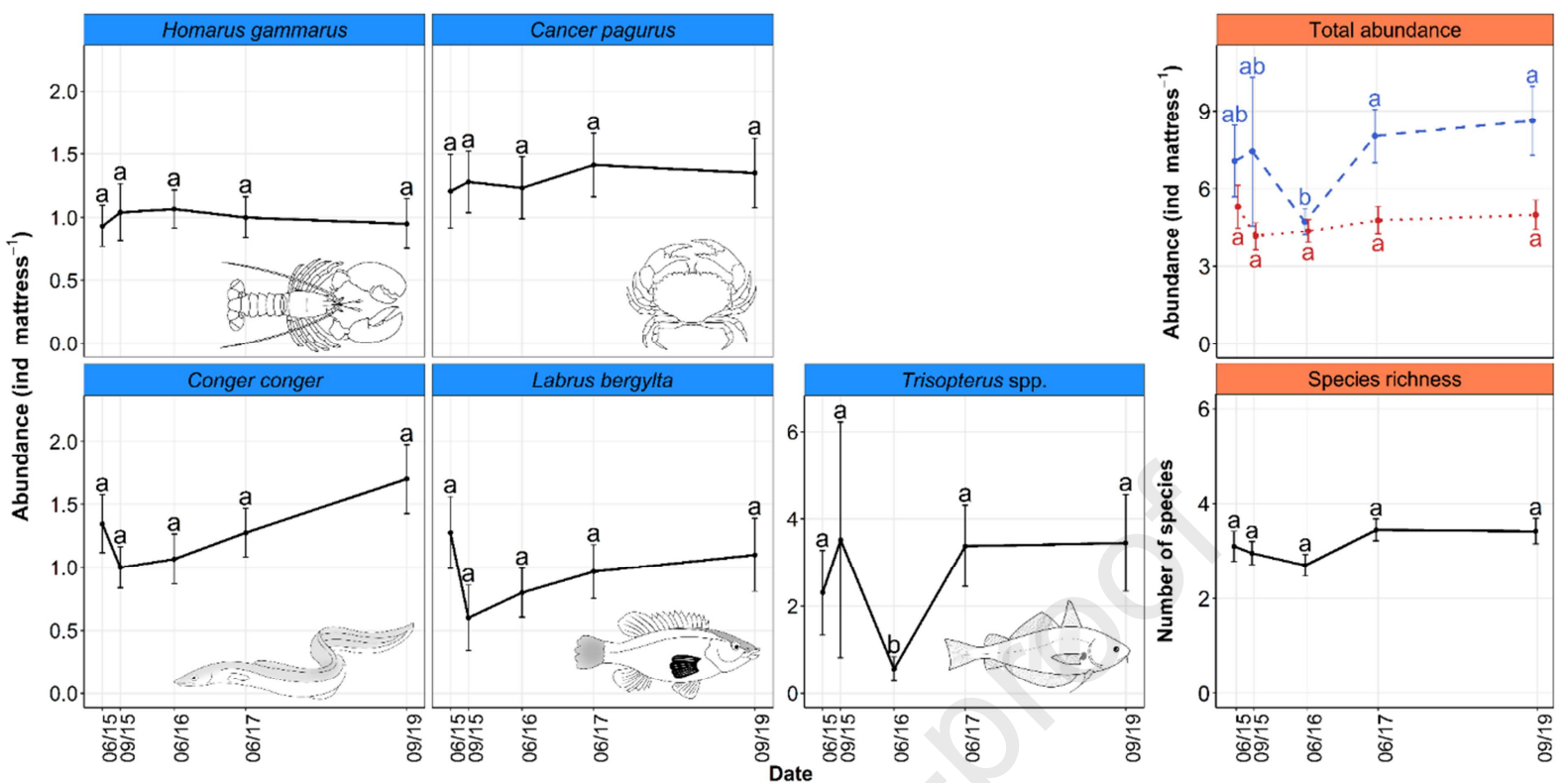

Figure 2 : Changes in mean specific abundances of the 5 target taxa (average number of individuals per mattress \pm standard errors), in mean community abundance per mattress (blue dashed line when considering all species; red dotted line when excluding highly abundant Trisopterus spp.) and in mean species richness per mattress. Points labelled with different letters indicate significant differences. Only the mattresses surveyed at every campaign were considered.

\subsection{Temporal variation}

Although occupancy of individual mattresses varied slightly during the different campaigns (SI 2), mean abundance estimates across all mattresses did not significantly change for $H$. gammarus $\left(\chi^{2}=0.44, \mathrm{df}=4, \mathrm{p}=0.98\right)$, C. pagurus $\left(\chi^{2}=0.6, \mathrm{df}=4, \mathrm{p}=0.96\right)$, C. conger $\left(\chi^{2}=5.42, \mathrm{df}=4, \mathrm{p}=\right.$ $0.25)$ and L. bergylta $\left(\chi^{2}=5.46, \mathrm{df}=4, \mathrm{p}=0.24\right.$, Figure 3). Only Trisopterus spp. displayed significant abundance changes between campaigns $\left(\chi^{2}=26.42\right.$, df $=4, p<0.001$; Figure 3$)$ due to significantly lower abundances in June 2016 relative to other campaigns. Total community abundance (across all five taxa) per mattress significantly changed between campaigns $\left(\chi^{2}=14.49\right.$, df $=4, p<$ 0.001 ; Figure 3) as total abundance in June 2016 was significantly lower than in June 2017 and September 2019. This is most likely due to the previously described decline in Trisopterus spp. abundance in June 2016. Indeed, when excluding this taxon, there was no significant temporal change 
218 in total megafauna abundance $\left(\chi^{2}=1.91, \mathrm{df}=4, \mathrm{p}=0.75\right.$; Figure 3$)$. Species richness per mattress did not significantly change overtime either $(\mathrm{F}=1.78, \mathrm{df}=4, \mathrm{p}=0.14$; Figure 3$)$. conspecific or from different species (Table 3). We did not quantify these co-occurrences, but observed i) that co-occurrence is more frequent within caves than within holes, ii) that mobile fish species (i.e. L. bergylta and Trisopterus spp.) frequently co-occurred with conspecifics and as well as other species, and iii) that individuals from sedentary species (i.e. H. gammarus, C. pagurus and $C$. conger) rarely co-occurred (Table 3 ).

Table 3: Observed co-occurrence within a single cavity of individuals from the different target taxa. Based on video footages, the matrix reports on whether several individuals from the same or different species co-occurred at least one time within a hole $(H)$, or a cave $(C)$ cavity.

\begin{tabular}{|c|c|c|c|c|c|c|c|c|c|c|}
\hline \multirow[b]{2}{*}{ Homarus gammarus } & \multicolumn{2}{|c|}{$\begin{array}{l}\text { Homarus } \\
\text { gammarus }\end{array}$} & \multicolumn{2}{|c|}{$\begin{array}{c}\text { Cancer } \\
\text { pagurus }\end{array}$} & \multicolumn{2}{|c|}{$\begin{array}{l}\text { Conger } \\
\text { conger }\end{array}$} & \multicolumn{2}{|c|}{$\begin{array}{l}\text { Trisopterus } \\
\text { spp. }\end{array}$} & \multicolumn{2}{|c|}{$\begin{array}{l}\text { Labrus } \\
\text { bergylta }\end{array}$} \\
\hline & - & - & & & & & & & & \\
\hline Cancer pagurus & - & - & - & C & & & & & & \\
\hline Conger conger & - & $\mathrm{C}$ & $\mathrm{H}$ & - & - & - & & & & \\
\hline Trisopterus spp. & - & C & - & $\mathrm{C}$ & - & C & $\mathrm{H}$ & C & & \\
\hline Labrus bergylta & - & - & - & - & - & - & $\mathrm{H}$ & $\mathrm{C}$ & $\mathbf{H}$ & C \\
\hline
\end{tabular}

Although we did not quantify their abundance (as they only marginally occurred), other species of benthic megafauna (including fish from the Blenniidae or Gobiidae families and other 233 wrasses species such as Labrus mixtus and Ctenolabrus rupestris, and crustaceans like Galathea sp. and Necora puber) were also regularly observed. 


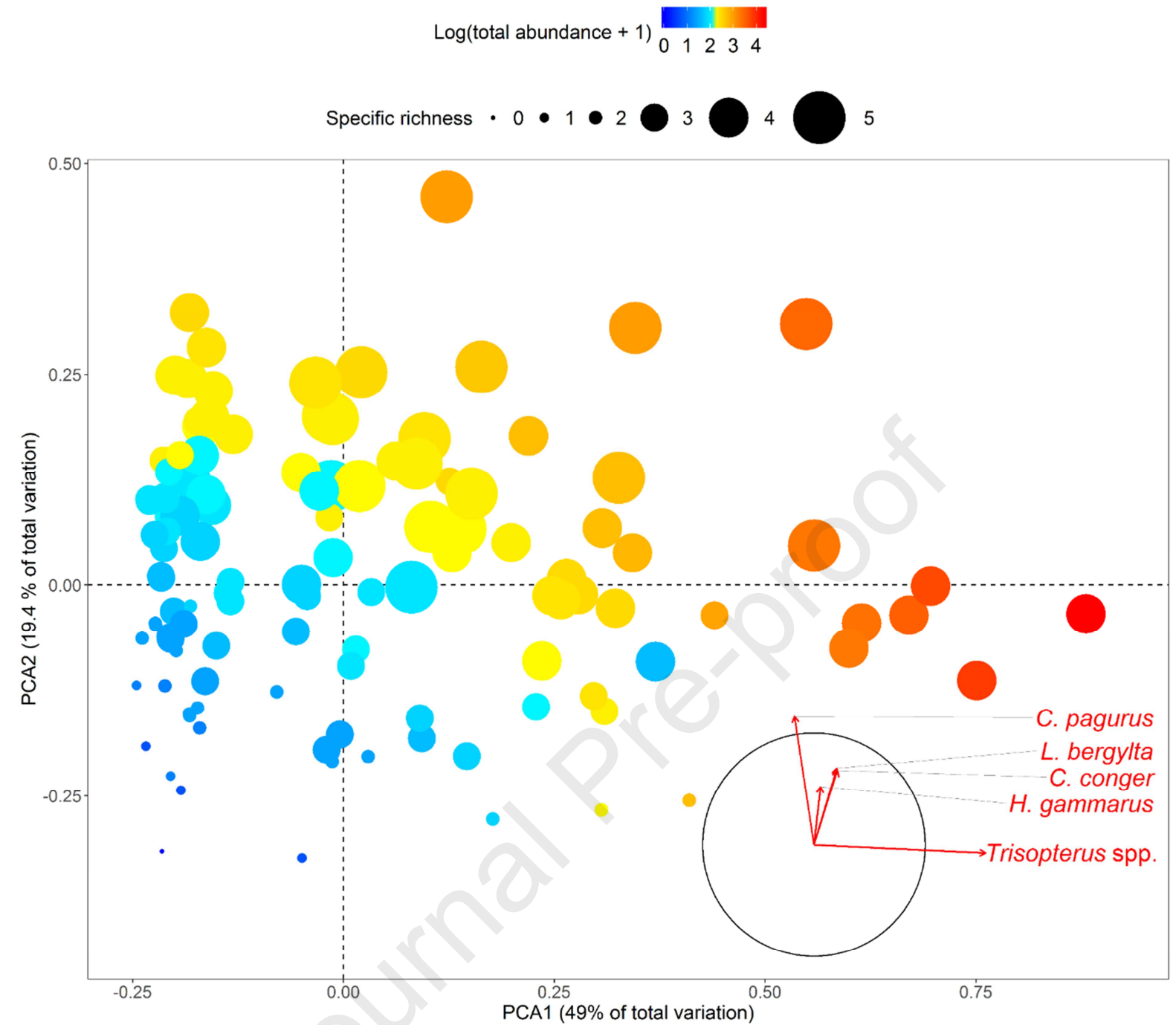

Figure 3: Principal Component Analysis (PCA) of log-transformed abundance data for the 5 target species. Each point represents a sample (i.e. a concrete mattress during a given campaign). Point size is proportional to species richness and colour indicates total megafauna abundance. Vector overlays show how species abundance correlates with the two first principal components.

Out of the 129 analysed samples, only 3 do not shelter any individuals of the target species.

Trisopterus spp. is the most abundant species (448 individuals counted in total), followed by $C$. pagurus (196 individuals), C. conger (183 individuals), L. bergylta (145 individuals) and finally $H$. gammarus (141 individuals).

The first two PCA axes capture $68.4 \%$ of the total variation (Figure 4). Axis PCA1 (49\% of total variation) is positively correlated to Trisopterus spp. abundance while the abundance of 4 of the 5 
taxa, mainly $C$. pagurus and then $L$. bergylta and $C$. conger positively correlates with axis PCA 2 (19.4\% of total variation; Figure 4). The colour and size codes used to visualise samples on the PCA also illustrates that both species richness and total abundance per mattress are positively correlated with the two first axes (Figure 4). PCA ordination highlights a large gradient of colonisation among samples, from low-abundance and low-richness samples (in the bottom left) to samples characterised by a high level of colonisation (in the top right of the plot).

\begin{tabular}{cccccccc} 
& & & \multicolumn{3}{c}{ Explained } & \multicolumn{2}{c}{ Correlation } \\
Environmental variable & F-value & p-value & $\lambda$ & $\%$ & & RDA1 & RDA2 \\
\hline Cave & 11.01 & $\mathbf{0 . 0 0 1}$ & 0.14 & $14 \%$ & $\mathbf{0 . 7 7}$ & 0.33 \\
\% Boulder & 8.185 & $\mathbf{0 . 0 0 1}$ & 0.1 & $10 \%$ & & $\mathbf{0 . 7 6}$ & -0.35 \\
Exposure & 4.872 & $\mathbf{0 . 0 0 6}$ & 0.06 & $6 \%$ & 0.31 & -0.39 \\
Hole & 1.794 & 0.146 & 0.02 & $2 \%$ & 0.24 & $\mathbf{0 . 7 1}$ \\
\% Pebble & 1.541 & 0.193 & 0.02 & $2 \%$ & 0.13 & $\mathbf{0 . 5 9}$ \\
Total & & & 0.34 & $34 \%$ & &
\end{tabular}

249

Table 4: Environmental variables selected in the RDA as well correlated to the variability in the abundance of the 5 target taxa colonising concrete mattresses at the Paimpol-Bréhat tidal test site cable (Monte Carlo permutation test in RDA with 999 permutations; $p<0.05)$. High correlation $(r>$ 0.5) between environmental variables and the first two RDA axes are highlighted in bold.

In the RDA (Figure 5), the environmental variables that best correlate to variability in megafauna composition are, in order of importance, number of caves, percentage of boulders, exposure to current, number of holes and finally percentage of pebbles (Table 4). These 5 variables capture $34 \%$ of the total variability in megafauna composition (Table 4; axis 1 and axis 2 explains $21.74 \%$ and $2.63 \%$ of

259 the total variation, respectively, Figure 5). Results of the RDA (Figure 5) are consistent with those of 260 the PCA (Figure 4). Number of caves present below the mattresses and percentage of boulders 261 correlate positively with RDA axis 1, while number of holes and percentage of pebbles mainly correlate positively with RDA axis 2 (Figure 5, Table 4). 

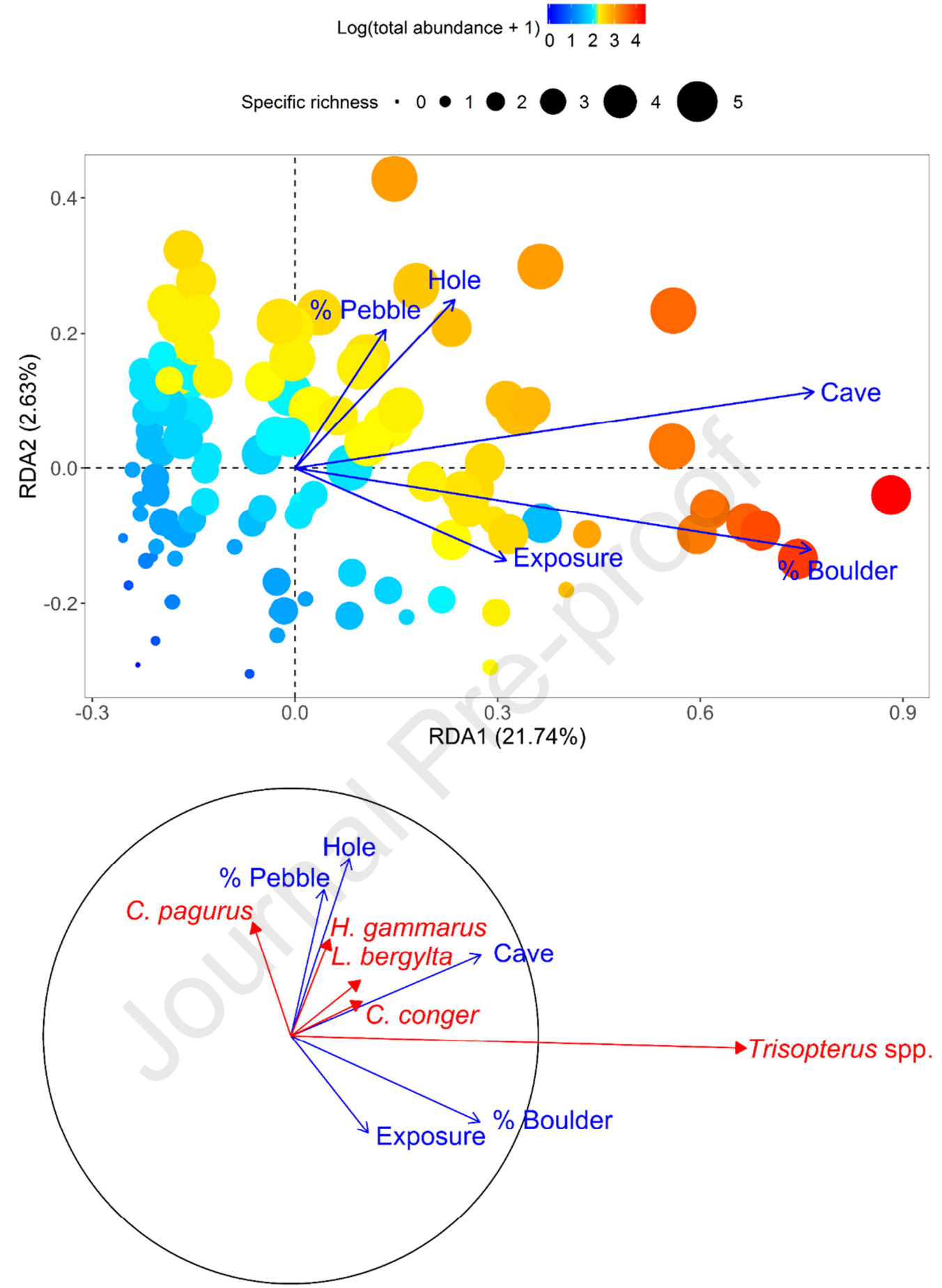

Figure 4: Redundancy analysis (RDA) ordination plots of axes 1 and 2 showing (A) samples (i.e. a concrete mattress during a given campaign, points) in relation to environmental variables (blue arrows); and (B) target megafauna species (red arrow) in relation to environmental variables (blue arrows). A different scaling was used for each panel, so environmental variables projection on the RDA should be used to reconcile both parts of the Figure. Axes 1 and 2 together explain $24.37 \%$ of the total taxonomic variation. Point size corresponds to associated species richness and point colour to associated total megafauna abundance. 
Note that samples with high abundance of Trisopterus spp. (to the right of the RDA) are associated with relatively high numbers of caves and percentages of boulders (Figure 5). On the other hand, high abundances of $C$. pagurus and H. gammarus occur on mattresses with high numbers of holes and percentage of pebbles. L. bergylta and C. conger are correlated with high number of caves and holes (Figure 5). Finally, samples with low diversity and low total abundance exhibited relatively small numbers of both types of cavity (holes or caves) and low percentages of pebbles and boulders (Figure 5).

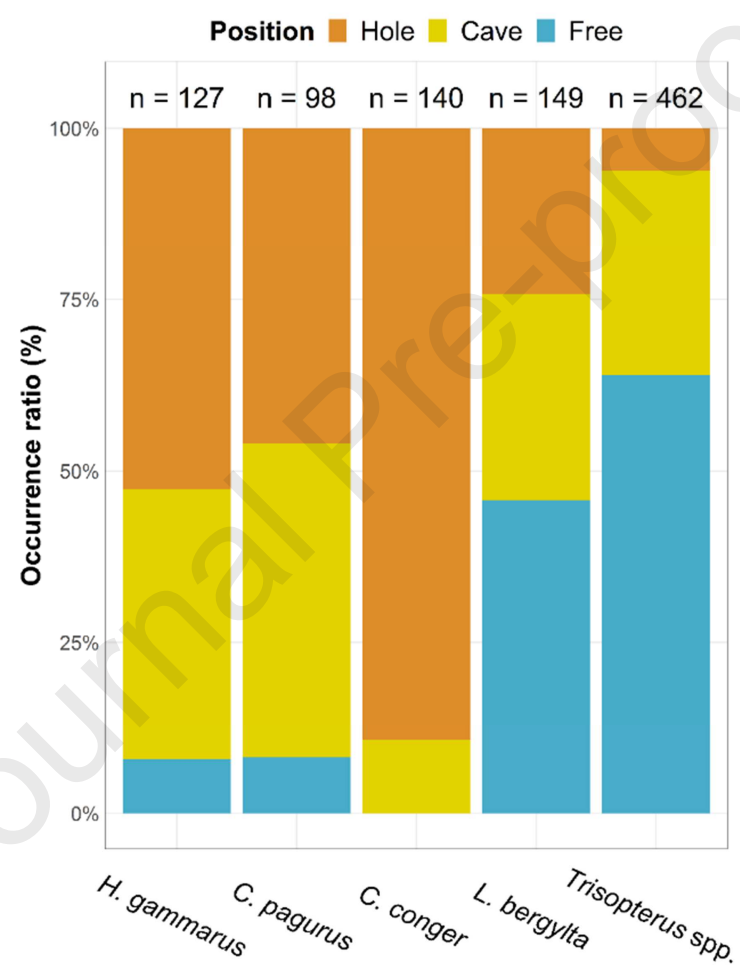

Figure 5 : Relative frequency of locations (either inside a "hole", inside a "cave", or free-moving out of any cavities) in which the 6 target species were detected, based on analyses of 169 video footages.

According to video footages, conger preferentially shelters within hole cavity $(89,3 \%$ of sheltered individuals observed on videos are in holes), whereas the two species of Trisopterus commonly shelter within cave cavities (for sheltered individuals, $83 \%$ found in caves; Figure 6). Conversely, edible crab, European lobster and Ballan wrasse do not show any clear habitat preference as they appear to randomly shelter in either cavity types (specific proportions of individuals sheltering in caves are 50\%, 42.7\% and 55.6\%, respectively; Figure 6). 


\section{DISCUSSION}

By combining in situ visual census by divers and video analysis, our results help to characterise how MRE facilities can enhance benthic megafauna diversity by providing artificial reefs. Specifically, our findings help: (i) characterise the habitat potential of concrete mattresses deployed to anchor an unburied power cable; (ii) disentangle how interactions between artificial reef and natural substrate determine the effectiveness of the 'reef effect' and (iii) to a lesser extent identify fine-scale habitat preferences of the 5 target species.

\subsection{Habitat potential of cable stabilizing structures}

MRE structures create additional potential habitat for benthic megafauna, as shown by several studies on colonisation (Krone et al., 2017; Langhamer and Wilhelmsson, 2009; Reubens et al., 2011; Wilhelmsson and Langhamer, 2014). On the subsea power cable of Paimpol-Bréhat, concrete mattresses offer a suitable habitat for large crustaceans and fish, at least for the 5 taxa targeted during our five-year monitoring. This result corroborates with previous studies that showed that these target species are known to be attracted by a number of artificial hard substrates, either associated with MRE facilities (Krone et al., 2017; Langhamer and Wilhelmsson, 2009; Reubens et al., 2011) or with other types of man-made structures (Castège et al., 2016; Charbonnel et al., 2000; Fabi et al., 2004; Jensen et al., 2000b, 1994; Santos et al., 2005).

In our study, one mattress is on average inhabited by 1 to 2 individuals of $C$. conger, $H$. gammarus and C. pagurus, corresponding to species-specific density of around 0.1 individuals per $\mathrm{m}^{2}$. By extrapolating these density estimates to all the 120 mattresses stabilising the power cable, the associated populations inhabiting these structures could be up to around $125 \mathrm{H}$. gammarus, $162 \mathrm{C}$. conger, 162 C. pagurus, 119 L. bergylta and 357 Trisopterus spp. These density estimates are smaller than others reported in the literature. Krone et al. (2017) showed that scour protections of a wind turbine foundation ( $1 \mathrm{~m}$ high and around $30 \mathrm{~m}$ diameters) in the German Bight (North Sea) were inhabited by several thousand of $C$. pagurus individuals, i.e. a density of $\sim 7$ ind $\mathrm{m}^{-2}$. Note, however that these estimates by Krone et al. (2017) include all life stages (including juveniles, which we missed in our visual surveys). Similar scour protection devices were found to host dense schools of T. luscus 
on a Belgian wind farm (Reubens et al., 2011). With an average density estimated at 14 ind $\mathrm{m}^{-2}$, total T. luscus population within the windfarm was estimated at about 22,000 individuals. Langhamer and Wilhelmsson (2009) highlighted colonisation of fish and crustacean on wave energy foundations (1 m high and $3 \mathrm{~m}$ diameters) in the North Sea, with a mean density of around 5 edible crabs per foundation, being $\sim 0.7$ ind $\mathrm{m}^{-2}$. Finally, Jensen et al. (1994) estimated that within the Poole Bay artificial reef, each reef unit ( $1 \mathrm{~m}$ high by $4 \mathrm{~m}$ of diameter) made up of several blocks $(40 \times 20 \times 20$ $\mathrm{cm}$ ) sheltered between 2 and $3 \mathrm{H}$. gammarus individuals (i.e. density up to $0.25 \mathrm{ind}^{-2}$ ). The fact that density values found in our study are smaller than those reported in the literature may be mainly explained by differences in surrounding natural habitats. In soft-sediment-dominated areas (e.g. the North sea), the number of shelters provided by natural habitat surrounding artificial reef is very low. Thus, mobile individuals are likely to find shelter in artificial reefs due to the low complexity of the natural habitat. The attraction effect is therefore likely stronger on soft-sediment bottoms relative to structurally-complex seafloor. In our case, natural hard substrate providing shelters are present in the wider area giving other options for this species. Another point can come from the basic shape of concrete mattresses, which are less complex than scour protections or wave-energy foundations.

It is noteworthy that target species abundance estimates were constant during our five-year monitoring. This absence of temporal variation suggests that $i$ ) colonisation of mattresses by mobile megafauna reached a plateau in less than 2 years after their deployment (first campaign was in June 2015 i.e. 2 years after the deployment of the mattresses) and ii) that target species may be permanent, rather than temporary residents of the mattresses. Our results are consistent with earlier findings of rapid colonisation of artificial reefs by megafauna: Jensen et al. (1994) showed that $H$. gammarus, $C$. pagurus, T. luscus and different species of wrasses can colonise artificial reefs within 3 weeks of their deployment. Moreover, biological traits related to mobility can to some extent support observed patterns of species-specific positioning around the mattress. Concerning H. gammarus, two modes of behaviour may exist: a mobile phase, with migration between different reefs, and a territorial phase where lobster individuals stay in close proximity to a chosen site/shelter (Jensen et al., 1994). $H$. gammarus can be highly loyal to its refuge, as showed by Jensen et al. (1994): $21 \%$ of lobsters caught on a reef unit stayed on it for more than 100 days. Labrus bergylta and other Labridae are also 
territorial species dwelling in the vicinity of an identified reef unit (Jensen et al., 1994; Villegas-Ríos

et al., 2013). Results from a mark-recapture programme suggest that a wide proportion of Trisopterus luscus individuals are bound to the same artificial reef units, which serve as a "home reef" (Fowler et al., 1999).

The degree of colonisation of individual mattresses appears highly dependent on the number and type of available shelters. Both these features condition how an artificial reef artificially enhances the carrying capacity of the local environment (Bohnsack, 1989; Eggleston et al., 1992; Pickering and Whitmarsh, 1997). As each species exhibits specific habitat preferences, the variety of shelters also largely explains the species composition of artificial reefs (Anderson et al., 1989; Beets and Hixon, 1994; Chandler et al., 1985; Pickering and Whitmarsh, 1997; Smith et al., 1979). Optimisation of MRE facilities through basic designs (e.g. with creation of manufactured holes of different sizes) has been shown to enhance their attractivity for benthic species (Langhamer and Wilhelmsson, 2009). The concrete mattresses of Paimpol-Bréhat were not designed to effectively provide additional habitat for marine fauna but to stabilise the submarine power cable and prevent fishing gear hooking. The two types of shelters we identified, namely holes and caves, present different physical characteristics: holes are narrow (around $20 \mathrm{~cm}$-wide) while caves can be much wider (around $1 \mathrm{~m}$-wide for the biggest caves). Total space availability likely explains why several individuals were more frequently observed to co-occur within caves than within holes. Note, also, that the two different types of cavities also host distinct groups of species. While L. bergylta shelters in both type of cavities, Trisopterus spp. show a clear habitat preference for caves. Trisopterus spp. are known to colonise rocky habitats with numerous and wide cavities such as caves, crevices or wrecks for shelters against tidal current (Jensen et al., 1994; Krone et al., 2013). Consequently, they shelter to a limited extent in holes and favour wide caves that can fit a whole school. This schooling behaviour conditions the species preference for larger caves, as highlighted by the high correlation between Trisopterus spp. abundance and the number of caves available below concrete mattresses. Our results also highlight that holes constitute the preferred habitat for $C$. conger. This solitary species is known to shelter in narrow cavities, the holes of the mattress constitute narrow and linear shelters which fit perfectly the shape of the adults, compared to the caves which are too wide. Adult European lobster individuals use physical shelters to 
avoid predators and being swept by strong tidal currents (Addison and Lovewell, 1991). Given the high tidal currents that can occur at the Paimpol-Bréhat tidal site (up to $3 \mathrm{~m} \mathrm{~s}^{-1}$ ), mattresses thus provide an adequate shelter to lobsters. Lobsters typically select dark shelters that fit their body size closely (sometimes with physical contact; Wahle et al., 2013). Although H. gammarus shows a subtle preference for mattresses with holes, this species is found in both cavities in equal proportions, suggesting that narrow caves can also be appealing to lobsters. Less information is available concerning sheltering behaviour and preferences of $C$. pagurus but the species has been reported to compete with lobsters for shelter so it is likely to display similar habitat preferences (Richards and Cobb, 1986). Contrastingly to the European lobster, C. pagurus individuals are known to escape predators by rapidly burrowing themselves in sandy habitats (Hudon and Lamarche, 1989). This burrowing behaviour may allow $C$. pagurus to colonise a wider variety of mattresses relative to lobster, including those exhibiting high proportions of soft sediments.

Among our target species, three groups can be discerned based on their habitat use on artificial reefs: (i) solitary and nocturnal species found in shelters during the day, such as $C$. conger, $H$. gammarus and C. pagurus; (ii) solitary and diurnal species found in shelters during the night, such as L. bergylta; and (iii) gregarious species that display a nocturnal activity, such as the two species of Trisopterus. Because of these overlaps in their biological traits, the three solitary and nocturnal species (i.e. C. conger, H. gammarus and C. pagurus) are likely to compete with each other for available artificial shelters. Although we did not directly observed competition between them, the rare cooccurrence within a single cavity of individuals from these three species could be the result of their competition for similar shelters. The different diel behaviours of the target species suggest a possible day/night shift in mattresses occupancy, as observed for other artificial (Santos et al., 2002) and natural reefs (Mallet et al., 2016; Myers et al., 2016). This day/night shift may introduce a bias in our counting procedure. Considering that all diving surveys occurred during the daytime, counts of diurnal species can be underestimated due to their temporary absence in the vicinity of the mattresses during the surveys. On the contrary, counts of nocturnal species are likely more accurate because individuals were mostly found motionless within mattresses cavities during the day. Furthermore, Trisopterus spp. proceeds to tidal migration in addition to day/night cycle, which may be another source of bias when 
evaluating its occupancy rate. Schools of T. luscus are found to be more congregated and closer to artificial reef units during high current speeds $\left(>0.3 \mathrm{~m} \mathrm{~s}^{-1}\right)$, and to be more dispersed and further from the reef during low current speeds $\left(<0.1 \mathrm{~m} \mathrm{~s}^{-1}\right.$; Fowler et al., 1999). Considering that all diving surveys occurred during slack tides (i.e. low speed currents), Trisopterus spp. abundance is possibly underestimated. In order to study in greater detail these community changes at the mattress scale resulting from the activity rhythms of the different megafauna species, the use of continuous video recording over several tide and day/night cycles could be useful (Aguzzi et al., 2013; Mallet et al., 2016; Weiss et al., 2009). Furthermore, the use of continuous video recording could help characterise biological interactions between the different megafauna species, such as competition for shelter associated with these artificial structures (Weiss et al., 2009).

\subsection{Interaction of artificial reef with local environment}

Differences in megafauna colonisation originate from the variability in local environmental conditions around each mattress: interaction between mattress and heterogeneous natural bottom directly influences the number and types of cavities available. Previous studies showed that environmental variables, such as bottom types, depth, hydrodynamic conditions, sediment dynamics or distance to natural reef, significantly impact the colonisation of artificial reefs (Ambrose and Swarbrick, 1989; Bohnsack et al., 1991; Bombace et al., 1994; Foster et al., 1994; Godoy et al., 2002; Noh et al., 2017).

Our results reveal that the higher the proportion of boulders, which is positively correlated with high hydrodynamic conditions, the higher the number of caves. Indeed, the presence of boulders creates an irregular seafloor topography and prevent the edges of mattress from fitting flush with it, thus creating overhanging space under the mattresses i.e. caves. Alexander et al. (2013) showed that seafloor complexity underneath a flat concrete block plays an important role as it directly impacts the volume available for colonisation. On the other hand, the number of holes available increases with the percentage of pebbles. However, in the presence of pebbles, caves do not form under the mattresses, but holes remain as open cavities between the adjacent concrete blocks. Although less colonised than mattress with caves, these holes provide shelters to C. pagurus, H. Gammarus, $C$. conger and $L$. bergylta. Finally, when the seafloor is dominated by sand and shell debris, the number of cavities is 
very low because, $i$ ) the flatness of the seafloor prevents the creation of caves, and $i$ ) accretion of sand and shell debris caused by the presence of the mattress often fills up existing holes. To summarise, holes constitute a narrow and deep cavity inherent to the way mattress is manufactured, but its availability can be impacted by the degree that it is filled by the sediment, which depends on local sediment dynamics. Caves constitute more or less narrow cavities with large openings, which only originate from the interaction between mattress and the local topography of the site. Here, we only differentiated these two types of cavities, but a more precise description of their physical features (e.g. through the use of quantitative criteria such as depth, size and shape of the entrance) would help better quantify mattress reef properties (Alexander, 2011).

Colonising an artificial reef also depends on distance to closest natural reefs (Ambrose and Swarbrick, 1989; Jessee et al., 1985). The closer to existing natural hard habitat, the higher the probability for artificial reefs to attract transient species (Campos and Gamboa, 1989; Potts and Hulbert, 1994). When deployed closely to existing natural reefs, artificial reefs essentially extend the amount of hard habitat with direct benefits for hard-substrate species recruitment (Danner et al., 1994). In our case, it is unlikely that distance to natural reefs influences mobile megafauna composition on mattresses. Since mattresses are installed between large shallow rocky shelves, their distance to natural rocky habitat are considered as low (less than $1 \mathrm{~km}$ ) and therefore relatively homogeneous. Computing precise distances between each mattress and the nearest natural reef would be difficult due to the very complex shape of the $10 \mathrm{~m}$ and $5 \mathrm{~m}$ isobaths in this area.

Finally, these structures associated with submarine power cables are not a classic artificial reef in the sense that the current transiting through cables generates electromagnetic fields. A lack of knowledge still exists concerning the impact of these anthropogenic electromagnetic fields on marine fauna (Taormina et al., 2018). This can potentially impact species capable of electroreception and/or magnetoreception through effects on predator/prey interactions, avoidance/attraction behaviour, navigation/orientation capabilities or induce physiological and developmental effects (Copping et al., 2016; Hutchison et al., 2020). Over the course of this study, no electric current transited through the cable and the mattresses thus acted as a classic artificial reef, but further investigations should be conducted once electrical current passes through. 
447 specifically designed to act as a refuge for marine fauna, a five-year monitoring study (both in situ and 448 using videos) shows that they offer a suitable and stable habitat for at least 5 benthic megafauna 449 species. Interactions between local seafloor and hydrodynamic characteristics (substratum type, 450 topography, exposition to current etc.) and artificial reef units directly condition the variety and the

451 availability of shelters. In our study, these two factors, i.e. shelters shape and availability, largely 452 characteristics. 


\section{Acknowledgements}

458

The authors would like to thank Laura Taormina, Fernando Tempera, Natacha Go,

459 Olivier Dugornay, Xavier Caisey and Fabrice Pernet for their kind assistance.

\section{$460 \quad$ Funding}

461 This work is sponsored by the Région Bretagne, France Energies Marines and the

462 National Research Agency within the framework of Investments for the Future program under 463 reference ANR-10-IED-0006-17. 
Addison, J.T., Lovewell, S.R.J., 1991. Size composition and pot selectivity in the lobster(Homarus gammarus (1.)) and crab (cancer pagurus 1.) fisherieson the east coast of england. ICES J. Mar. Sci. 48, 79-90. doi:10.1093/icesjms/48.1.79

Aguzzi, J., Sbragaglia, V., Santamaría, G., Del Río, J., Sardà, F., Nogueras, M., Manuel, A., 2013. Daily activity rhythms in temperate coastal fishes: Insights from cabled observatory video monitoring. Mar. Ecol. Prog. Ser. 486, 223-236. doi:10.3354/meps10399

Alexander, T.J., 2013. Cryptic invertebrates on subtidal rocky reefs vary with microhabitat structure and protection from fishing. Mar. Ecol. Prog. Ser. 481, 93-104. doi:10.3354/meps10263

Alexander, T.J., 2011. Responses of temperate mobile macroinvertebrates to reef habitat structure and protection from fishing. University of Tasmania.

Ambrose, R.F., Swarbrick, S.L., 1989. Comparison of fish assemblages on artificial and natural reefs off the coast of southern California. Bull. Mar. Sci. 44, 718-733.

Anderson, T.W., Demartini, E.E., Roberts, D.A., 1989. The relationship between habitat structure, body size and distribution of fishes at a temperate artificial reef. Bull. Mar. Sci.

Beets, J., Hixon, M.A., 1994. Distribution, persistence, and growth of groupers (Pisces: Serranidae) on artificial and natural patch reefs in the Virgin Islands. Bull. Mar. Sci. 55, 470-483.

Bohnsack, J.A., 1989. Are high densities of fishes at artificial reefs the result of habitat limitation or behavioral preference. Bull. Mar. Sci. 44, 631-645. doi:March 1, 1989

Bohnsack, J.A., Harper, D.E., Mcclellan, D.B., Hulsbeck, M., 1994. Effects of Reef Size on Colonization and assemblage structure of fished at artificial reefs off southeastern Florida U.S.A. Bull. Mar. Sci. 55, 796-823.

Bohnsack, J.A., Johnson, D.L., Ambrose, R.F., 1991. Ecology of Artificial Reef Habitats and Fishes, in: Artificial Habitats for Marine and Freshwater Fisheries. ACADEMIC PRESS, INC., San Diego, pp. 61-107. doi:10.1016/b978-0-08-057117-1.50009-3

Bombace, G., Fabi, G., Fiorentini, L., Speranza, S., 1994. Analysis of the efficacy of artificial reefs located in five different areas of the Adriatic sea. Bull. Mar. Sci. 55, 559-580.

Broadhurst, M., Orme, C.D.L., 2014. Spatial and temporal benthic species assemblage responses with 
a deployed marine tidal energy device: A small scaled study. Mar. Environ. Res. 99, 76-84.

494

495

496

497

498

499

500

501

502

503

504

505

506

507

508

509

510

511

512

513

514

515

516

517

518

519

Campos, J.A., Gamboa, C., 1989. An artificial tire-reef in a tropical marine system: a management tool. Bull. Mar. Sci. 44, 757-766.

Castège, I., Milon, E., Fourneau, G., Tauzia, A., 2016. First results of fauna community structure and dynamics on two artificial reefs in the south of the Bay of Biscay (France). Estuar. Coast. Shelf Sci. 179, 172-180. doi:10.1016/j.ecss.2016.02.015

Chandler, C.R., Sanders, R.M., Landry, A.M., 1985. Effects of three substrate variables on two artificial reef fish communities. Bull. Mar. Sci. 37, 129-142.

Charbonnel, E., Francour, P., Harmelin, J.G., Bachet, G., 2000. Effects of Artificial Reef Design on Associated Fish assemnlages in the Cote Bleue Marine Park.pdf, in: Artificial Reefs in European Seas. Springer Netherlands.

Charbonnel, E., Serre, C., Ruitton, S., Harmelin, J., Jensen, A., 2002. Effects of increased habitat complexity on fish assemblages associated with large artificial reef units (French Mediterranean coast). ICES J. Mar. Sci. 59, S208-S213. doi:10.1006/jmsc.2002.1263

Copping, A., Sather, N., Hanna, L., Whiting, J., Zydlewsk, G., Staines, G., Gill, A., Hutchison, I., O’Hagan, A.M., Simas, T., Bald, J., Sparkling, C., Wood, J., Masden, E., 2016. Annex IV 2016 State of the Science Report: Environmental Effects of Marine Renewable Energy Development Around the World. doi:10.1097/JNN.0b013e3182829024

Danner, E.M., Wilson, T.C., Schlotterbeck, R.E., 1994. Comparison of rockfish recruitment of nearshore artificial and natural reefs off the coast of central California. Bull. Mar. Sci. 55, 333343.

Dannheim, J., Bergström, L., Birchenough, S.N.R., Brzana, R., Boon, A.R., Coolen, J.W.P., Dauvin, J.-C., De Mesel, I., Derweduwen, J., Gill, A.B., Hutchison, Z.L., Jackson, A.C., Janas, U., Martin, G., Raoux, A., Reubens, J., Rostin, L., Vanaverbeke, J., Wilding, T.A., Wilhelmsson, D., Degraer, S., 2020. Benthic effects of offshore renewables: identification of knowledge gaps and urgently needed research. ICES J. Mar. Sci. 77, 1092-1108. doi:10.1093/icesjms/fsz018

Dufournaud, N., 2018. Apport de la vidéo sous-marine pour l'étude de la colonisation par la 
mégafaune benthique des structures artificielles associées aux projets d'énergies marines renouvelables.

522

523

524

525

526

527

528

529

530

531

532

533

Eggleston, D.B., Lipcius, R.N., Miller, D.L., 1992. Artificial shelters and survival of juvenile Caribbean spiny lobster Panulirus argus: spatial, habitat, and lobster size effects. Fish. Bull. 90, $691-702$.

Fabi, G., Grati, F., Puletti, M., Scarcella, G., 2004. Effects on fish community induced by installation of two gas platforms in the Adriatic Sea. Mar. Ecol. Prog. Ser. 273, 187-197.

Ferreira, C.E.L., Coutinho, R., 2001. Community structure of shes and habitat complexity on a tropical rocky shore. Environ. Biol. Fishes 353-369.

Foster, K.L., Steimle, F.W., Muir, W.C., Kropp, R.K., Conlin, B.E., 1994. Mitigation potential of habitat replacement concrete artificial reef in Delaware Bay - preliminary results. Bull. Mar. Sci. $55,783-795$.

Fowler, A.J., Jensen, A.C., Collins, K.J., Smith, I.P., 1999. Age structure and diel activity of pouting on the Poole Bay artificial reef. J. Fish Biol. 54, 944-954. doi:10.1006/jfbi.1998.0918

Godoy, E.A.S., Almeida, T.C.M., Zalmon, I.R., 2002. Fish assemblages and environmental variables on an artificial reef north of Rio de Janeiro, Brazil. ICES J. Mar. Sci. 59, S138-S143. doi:10.1006/jmsc.2002.1190

Hackradt, C.W., Félix-Hackradt, F.C., García-Charton, J.A., 2011. Influence of habitat structure on fish assemblage of an artificial reef in southern Brazil. Mar. Environ. Res. 72, 235-247. doi:10.1016/j.marenvres.2011.09.006

Hooper, T., Austen, M., 2014. The co-location of offshore windfarms and decapod fisheries in the UK: Constraints and opportunities. Mar. Policy 43, 295-300. doi:10.1016/j.marpol.2013.06.011

Hudon, C., Lamarche, G., 1989. Niche segregation between American lobster Homarus americanus and rock crab Cancer irroratus. Mar. Ecol. Prog. Ser. 52, 155-168.

Hutchison, Z.L., Gill, A.B., Sigray, P., He, H., King, J.W., 2020. Anthropogenic electromagnetic fields (EMF) influence the behaviour of bottom-dwelling marine species. Sci. Rep. 10, 1-15. doi:10.1038/s41598-020-60793-x

Jensen, A.C., 2002. Artificial reefs of Europe: perspective and future. ICES J. Mar. Sci. 59, S3-S13. 
doi:10.1006/jmsc.2002.1298

549

550

551

552

553

554

555

556

557

558

559

560

561

562

563

564

565

566

567

568

569

570

571

572

573

574

575

Jensen, A.C., Collins, K.J., Lockwood, A.P.M., 2000a. Artificial Reef In European Seas. Springer Netherlands. doi:10.1007/978-94-011-4215-1

Jensen, A.C., Collins, K.J., Lockwood, A.P.M., Mallinson, J.J., Turnpenny, W.H., 1994. Colonization and Fishery Potential of a Coal-Ash Artificial Reef, Poole Bay, United Kingdom. Bull. Mar. Sci. $55,1263-1276$.

Jensen, A.C., Wickins, J., Bannister, C., 2000b. The Potential Use of Artificial Reefs to Enhance Lobster Habitat, in: Artificial Reefs in European Seas. Springer Netherlands, pp. 379-401. doi:10.1007/978-94-011-4215-1_23

Jessee, W.N., Carpenter, A.L., Carter, J.W., 1985. Distribution patterns and density estimates of fishes on a southern California artificial reef with comparisons to natural kelp- reef habitats. Bull. Mar. Sci. 37, 214-226.

Krone, R., Dederer, G., Kanstinger, P., Krämer, P., Schneider, C., Schmalenbach, I., 2017. Mobile demersal megafauna at common offshore wind turbine foundations in the German Bight (North Sea) two years after deployment - increased production rate of Cancer pagurus. Mar. Environ. Res. 123, 53-61. doi:10.1016/j.marenvres.2016.11.011

Krone, R., Gutow, L., Brey, T., Dannheim, J., Schröder, A., 2013. Mobile demersal megafauna at artificial structures in the German Bight - Likely effects of offshore wind farm development. Estuar. Coast. Shelf Sci. 125, 1-9. doi:10.1016/j.ecss.2013.03.012

Langhamer, O., 2012. Artificial Reef Effect in relation to Offshore Renewable Energy Conversion: State of the Art. Sci. World J. 2012, e386713. doi:10.1100/2012/386713

Langhamer, O., Wilhelmsson, D., 2009. Colonisation of fish and crabs of wave energy foundations and the effects of manufactured holes - A field experiment. Mar. Environ. Res. 68, 151-157. doi:10.1016/j.marenvres.2009.06.003

Legendre, P., Legendre, L., 1998. Numerical Ecology. Elsevier: Amsterdam/New-York.

Lima, J.S., Zalmon, I.R., Love, M., 2019. Overview and trends of ecological and socioeconomic research on artificial reefs. Mar. Environ. Res. 145, 81-96. doi:10.1016/j.marenvres.2019.01.010

Lindeboom, H., Degraer, S., Dannheim, J., Gill, A.B., Wilhelmsson, D., 2015. Offshore wind park 
monitoring programmes, lessons learned and recommendations for the future. Hydrobiologia 756, 169-180. doi:10.1007/s10750-015-2267-4

578

579

580

581

582

Lindeboom, H.J., Kouwenhoven, H.J., Bergman, M.J.N., Bouma, S., Brasseur, S., Daan, R., Fijn, R.C., de Haan, D., Dirksen, S., van Hal, R., Hille Ris Lambers, R., ter Hofstede, R., Krijgsveld, K.L., Leopold, M., Scheidat, M., 2011. Short-term ecological effects of an offshore wind farm in the Dutch coastal zone; a compilation. Environ. Res. Lett. 6, 1-13. doi:10.1088/1748$9326 / 6 / 3 / 035101$

Mallet, D., Vigliola, L., Wantiez, L., Pelletier, D., 2016. Diurnal temporal patterns of the diversity and the abundance of reef fishes in a branching coral patch in New Caledonia. Austral Ecol. 41, 733744. doi:10.1111/aec. 12360

Myers, E.M.V., Harvey, E.S., Saunders, B.J., Travers, M.J., 2016. Fine-scale patterns in the day, night and crepuscular composition of a temperate reef fish assemblage. Mar. Ecol. 37, 668-678. doi:10.1111/maec.12336

Noh, J., Ryu, J., Lee, D., Khim, J.S., 2017. Distribution characteristics of the fish assemblages to varying environmental conditions in artificial reefs of the Jeju Island, Korea. Mar. Pollut. Bull. 118, 388-396. doi:10.1016/j.marpolbul.2017.02.066

Oksanen, J., Blanchet, F.G., Friendly, M., Kindt, R., Legendre, P., McGlinn, D., Minchin, P.R., O’Hara, R.B., Simpson, G.L., Solymos, P., Henry, M., Stevens, H., Szoecs, E., Wagner, H., 2018. vegan: Community Ecology Package. R package version 2.4-6. https://CRAN.Rproject.org/package=vegan, $\mathrm{R}$ package.

Pickering, H., Whitmarsh, D., 1997. Artificial reefs and fisheries exploitation: A review of the "attraction versus production" debate, the influence of design and its significance for policy. Fish. Res. 31, 39-59. doi:10.1016/S0165-7836(97)00019-2

Polovina, J.J., Sakai, I., 1989. Impacts of artificial reefs on fishery production in Shimamaki, Japan. Bull. Mar. Sci. 44, 997-1003.

Potts, T.A., Hulbert, A.W., 1994. Structural influences of artificial and natural habitats on fish aggregations in Onslow Bay, North Carolina. Bull. Mar. Sci. 55, 609-622.

Reubens, J.T., Degraer, S., Vincx, M., 2011. Aggregation and feeding behaviour of pouting 
(Trisopterus luscus) at wind turbines in the Belgian part of the North Sea. Fish. Res. 108, 223 227. doi:10.1016/j.fishres.2010.11.025

Richards, R.A., Cobb, J.S., 1986. Competition for Shelter Between Lobsters (Homarus americanus) and Jonah Crabs (Cancer borealis): Effects of Relative Size. Can. J. Fish. Aquat. Sci. 43, 22502255.

RStudio Team, 2015. RStudio: Integrated Development for R. RStudio, Inc., Boston.

Santos, M.N., Monteiro, C.C., Gaspar, M.B., 2002. Diurnal variations in the fish assemblage at an artificial reef. ICES J. Mar. Sci. 59, 32-35. doi:10.1006/jmsc.2001.1166

Santos, M.N., Monteiro, C.C., Lasserre, G., 2005. Observations and trends on the intra-annual variation of the fish assemblages on two artificial reefs in Algarve coastal waters ( southern Portugal ). Sci. Mar. 69, 415-426.

Sherman, R.L., Gilliam, D.S., Spieler, R.E., 2002. Artificial reef design: Void space, complexity, and attractants. ICES J. Mar. Sci. 59, 196-200. doi:10.1006/jmsc.2001.1163

Smith, G.B., Hensley, D.A., Mathews, H.H., 1979. Comparative Efficacy of Artificial and Natural Gulf of Mexico Reefs as Fish Attractants, Florida Marine Research Publication. St. Petersburg, Florida.

Taormina, B., Bald, J., Want, A., Thouzeau, G., Lejart, M., Desroy, N., Carlier, A., 2018. A review of potential impacts of submarine power cables on the marine environment: Knowledge gaps, recommendations and future directions. Renew. Sustain. Energy Rev. 96, 380-391. doi:10.1016/j.rser.2018.07.026

Thierry, J.M., 1988. Artificial reefs in Japan - A general outline. Aquac. Eng. 7, 321-348. doi:10.1016/0144-8609(88)90014-3

Villegas-Ríos, D., Mucientes, G., Saborido-Rey, F., Alós, J., March, D., Palmer, M., 2013. Home range and diel behavior of the ballan wrasse, Labrus bergylta, determined by acoustic telemetry. J. Sea Res. 80, 61-71. doi:10.1016/j.seares.2013.02.009

Wahle, R.A., Castro, K.M., Tully, O., Cobb, J.S., 2013. Homarus, in: Lobsters: Biology, Management, Aquaculture \& Fisheries: Second Edition. Wiley Blackwell, pp. 221-258. 
632 Weiss, H.M., Lozano-Álvarez, E., Briones-Fourzán, P., Negrete-Soto, F., 2009. Using Red Light with

633

634

635

636

637

638

639

640

641

642

643

Fixed-site Video Cameras to Study the Behavior of the Spiny Lobster (Panulirus argus) and Associated Animals at Night and Inside Their Shelters. Mar. Technol. Soc. J. 40, 86-95. doi:10.4031/002533206787353213

Wickham, H., 2016. ggplot2: Elegant Graphics for Data Analysis. Springer-Verlag New York. doi:10.1007/978-0-387-98141-3

Wilhelmsson, D., Langhamer, O., 2014. The Influence of Fisheries Exclusion and Addition of Hard Substrata on Fish and Crustaceans, in: Shields, M.A., Payne, I.L.A. (Eds.), Marine Renewable Energy Technology and Environmental Interactions. Springer, pp. 49-60.

Wilson, J.C., Elliott, M., 2009. The habitat-creation potential of offshore wind farms. Wind Energy 12 , 203-212. doi:10.1002/we.324 
Journal Pre-proof

Environmental variable

F-value $p$-value

$\begin{array}{cc}\lambda & \% \\ 0.14 & 14 \%\end{array}$

RDA1 RDA2

$\%$ Boulder

$\begin{array}{ll}8.185 & 0.001\end{array}$

$4.872 \quad 0.006$

$0.1 \quad 10 \%$

$0.77-0.33$

Exposure

$1.794 \quad 0.146$

$0.06 \quad 6 \%$

$\mathbf{0 . 7 6}-0.35$

Hole

$\%$ Pebble

$1.541 \quad 0.193$

$0.02 \quad 2 \%$

$0.31 \quad-0.39$

$0.02 \quad 2 \%$

0.24

0.71

Total

$0.34 \quad 34 \%$

0.59 


\begin{tabular}{|c|c|c|c|c|c|c|c|c|c|}
\hline \multirow[b]{2}{*}{ Homarus gammarus } & \multicolumn{2}{|c|}{$\begin{array}{c}\text { Homarus } \\
\text { gammarus }\end{array}$} & \multicolumn{2}{|c|}{$\begin{array}{c}\text { Cancer } \\
\text { pagurus }\end{array}$} & \multicolumn{2}{|c|}{$\begin{array}{l}\text { Conger } \\
\text { conger }\end{array}$} & \multicolumn{2}{|c|}{$\begin{array}{c}\text { Trisopterus } \\
\text { spp. }\end{array}$} & $\begin{array}{c}\text { Labrus } \\
\text { bergylta }\end{array}$ \\
\hline & - & - & & & & & & & \\
\hline Cancer pagurus & - & - & - & C & & & & & \\
\hline Conger conger & - & C & $\mathrm{H}$ & - & - & - & & & \\
\hline Trisopterus spp. & - & C & - & C & - & C & $\mathrm{H}$ & C & \\
\hline Labrus bergylta & - & - & - & - & - & - & $\mathrm{H}$ & $\mathrm{C}$ & $\mathrm{H}$ \\
\hline
\end{tabular}




\begin{tabular}{lll} 
Campaign & Mattresses & Zone \\
\hline June 2015 & 45 & $\begin{array}{l}\text { A-B-C-D } \\
\text { A-C(only C25 } \\
\text { to C35)-D }\end{array}$ \\
September 2015 & 30 & $\begin{array}{l}\text { A-C-D } \\
\text { June 2016 }\end{array}$ \\
June 2017 & 37 & $\begin{array}{l}\text { A-C-D } \\
\text { A-C(only C25 } \\
\text { to C35) }\end{array}$
\end{tabular}




\begin{tabular}{|c|c|c|c|c|c|c|}
\hline & rancavic & CIII & $\begin{array}{l}1 \text { Pre-p } \\
\text { vismin }\end{array}$ & Irecain & Irmin & trias \\
\hline \multirow{5}{*}{ 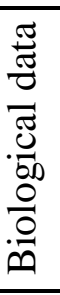 } & Homarus gammarus & count & in situ & 1.1 & 0 & 5 \\
\hline & Cancer pagurus & count & in situ & 1.5 & 0 & 5 \\
\hline & Conger conger & count & in situ & 1.4 & 0 & 4 \\
\hline & Trisopterus spp. & count & video & 3.5 & 0 & 68 \\
\hline & Labrus bergylta & count & video & 1.1 & 0 & 6 \\
\hline \multirow{9}{*}{ 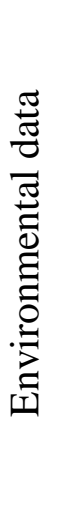 } & Sand proportion & $\%$ & video & $67 \%$ & $0 \%$ & $100 \%$ \\
\hline & Pebble proportion & $\%$ & video & $27 \%$ & $0 \%$ & $100 \%$ \\
\hline & Boulder proportion & $\%$ & video & $6 \%$ & $0 \%$ & $89 \%$ \\
\hline & Number of holes & count & video & 10.2 & 3 & 12 \\
\hline & Number of caves & count & video & 9.2 & 0 & 28 \\
\hline & Bottom-current velocity & $\mathrm{m} \mathrm{s}^{-1}$ & GIS & 0.71 & 0.65 & 0.99 \\
\hline & Exposure & $\circ$ & GIS & 93.8 & 12.7 & 163.8 \\
\hline & Distance to $5 \mathrm{~m}$ isobath & $\mathrm{m}$ & GIS & 500.2 & 149.7 & 791.2 \\
\hline & Distance to $10 \mathrm{~m}$ isobath & $\mathrm{m}$ & GIS & 245.1 & 62 & 403.5 \\
\hline
\end{tabular}




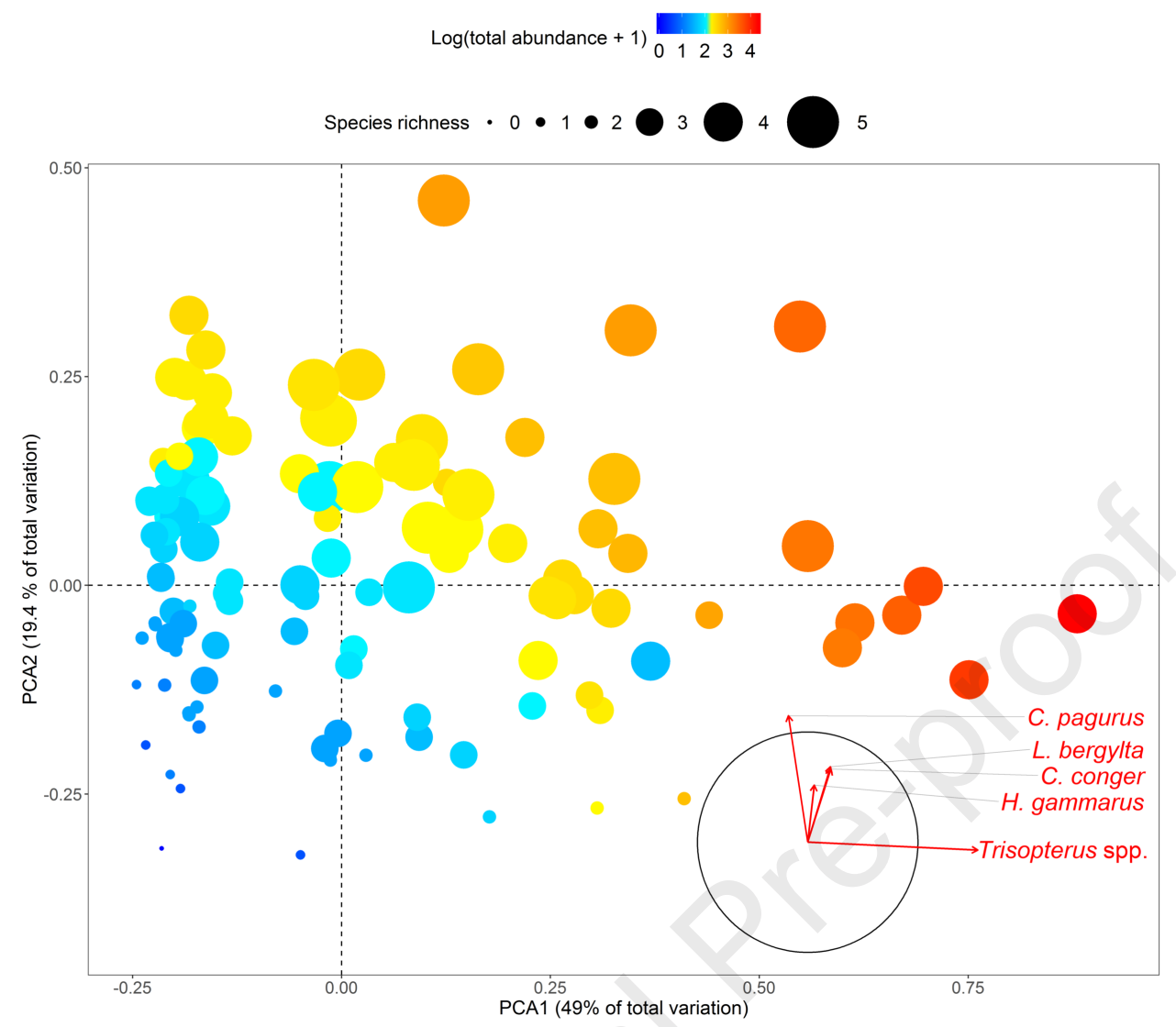




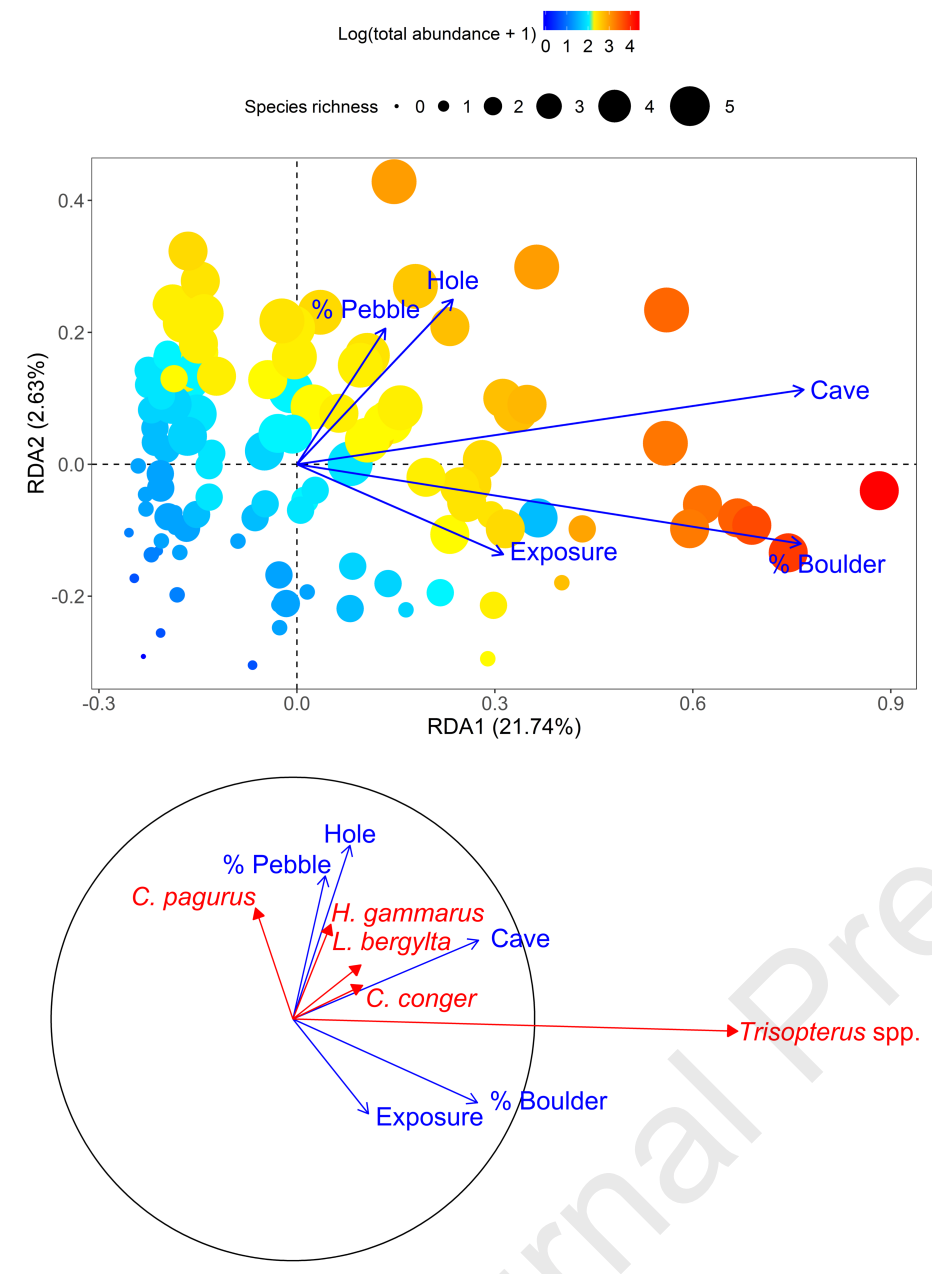




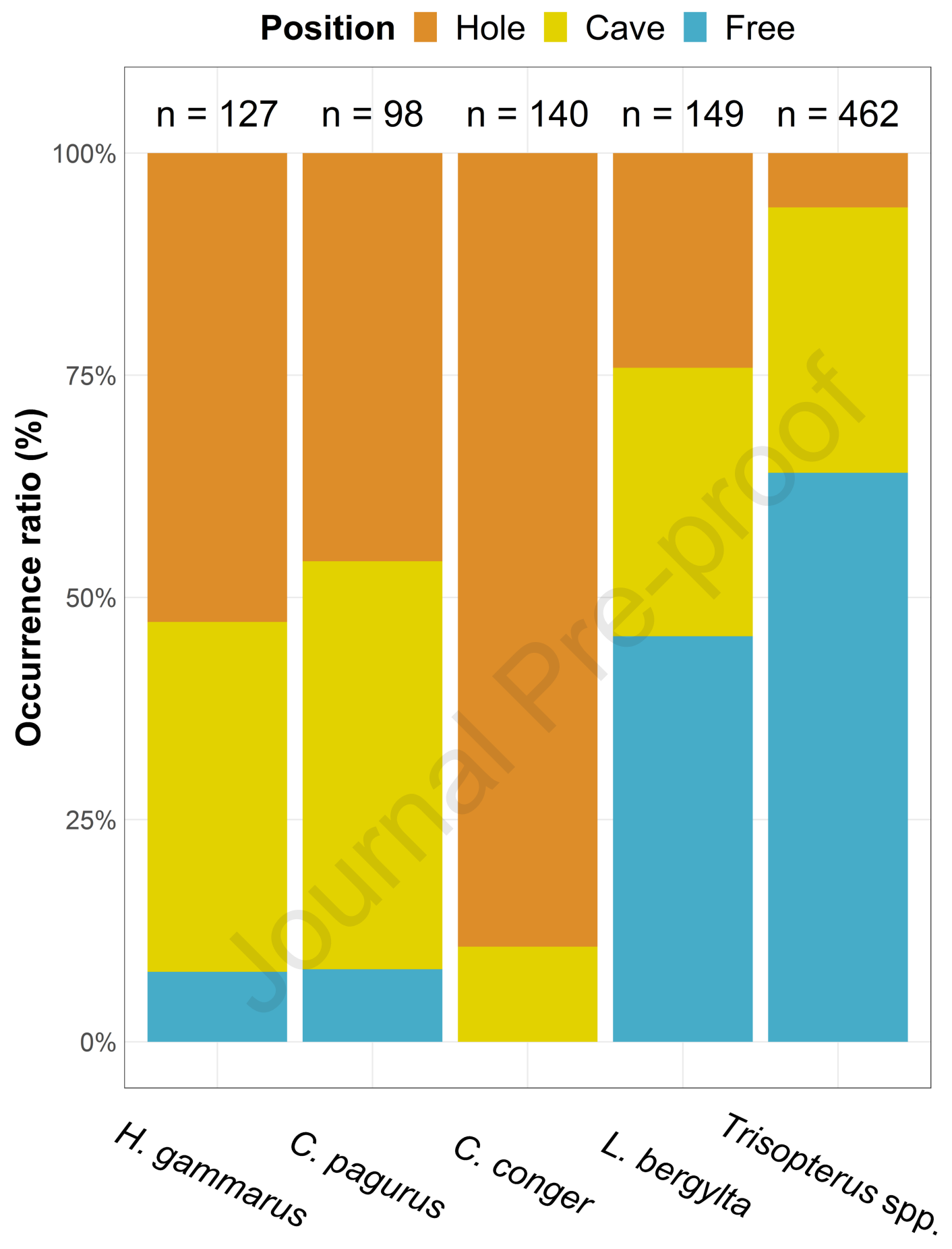




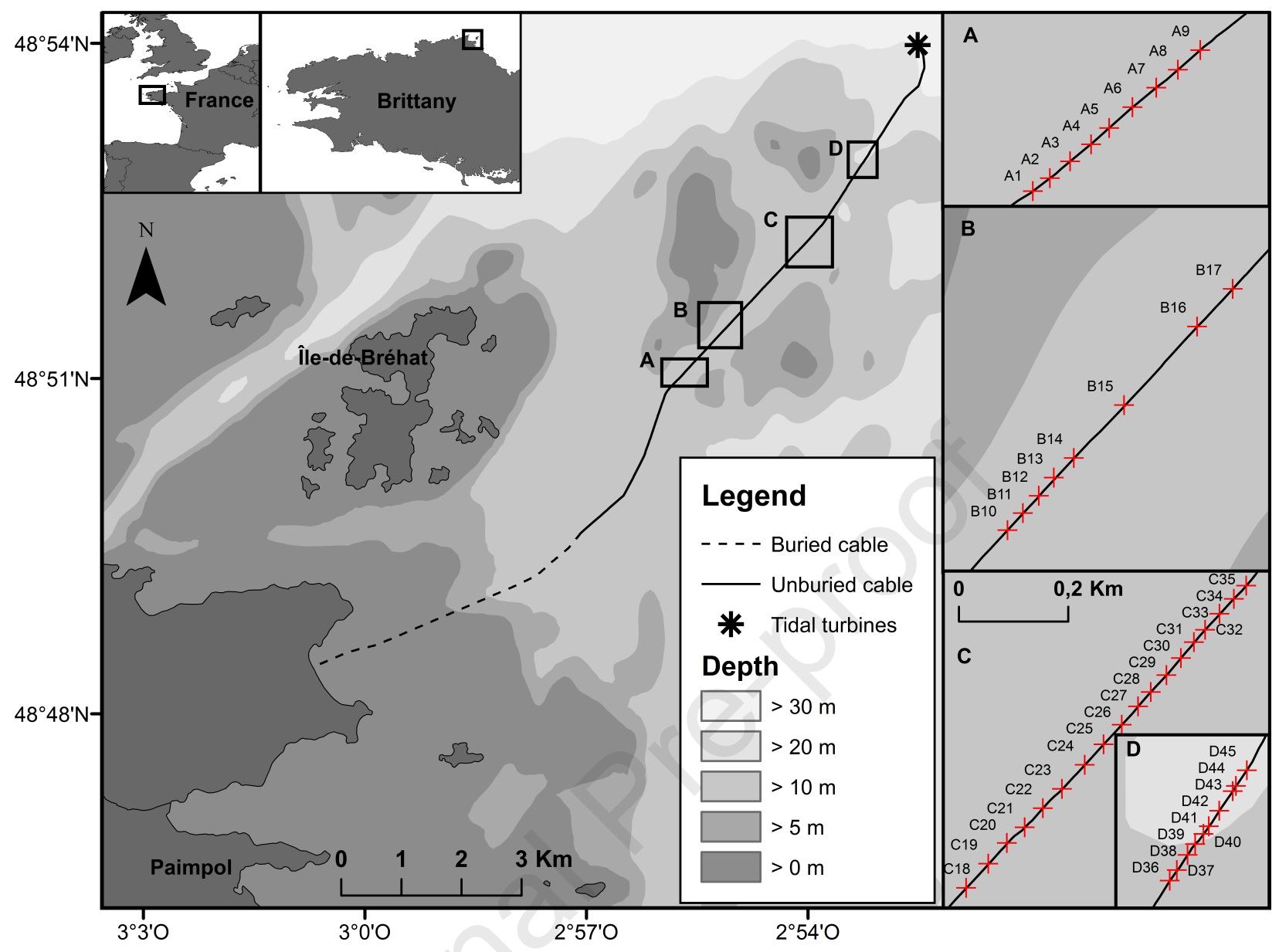




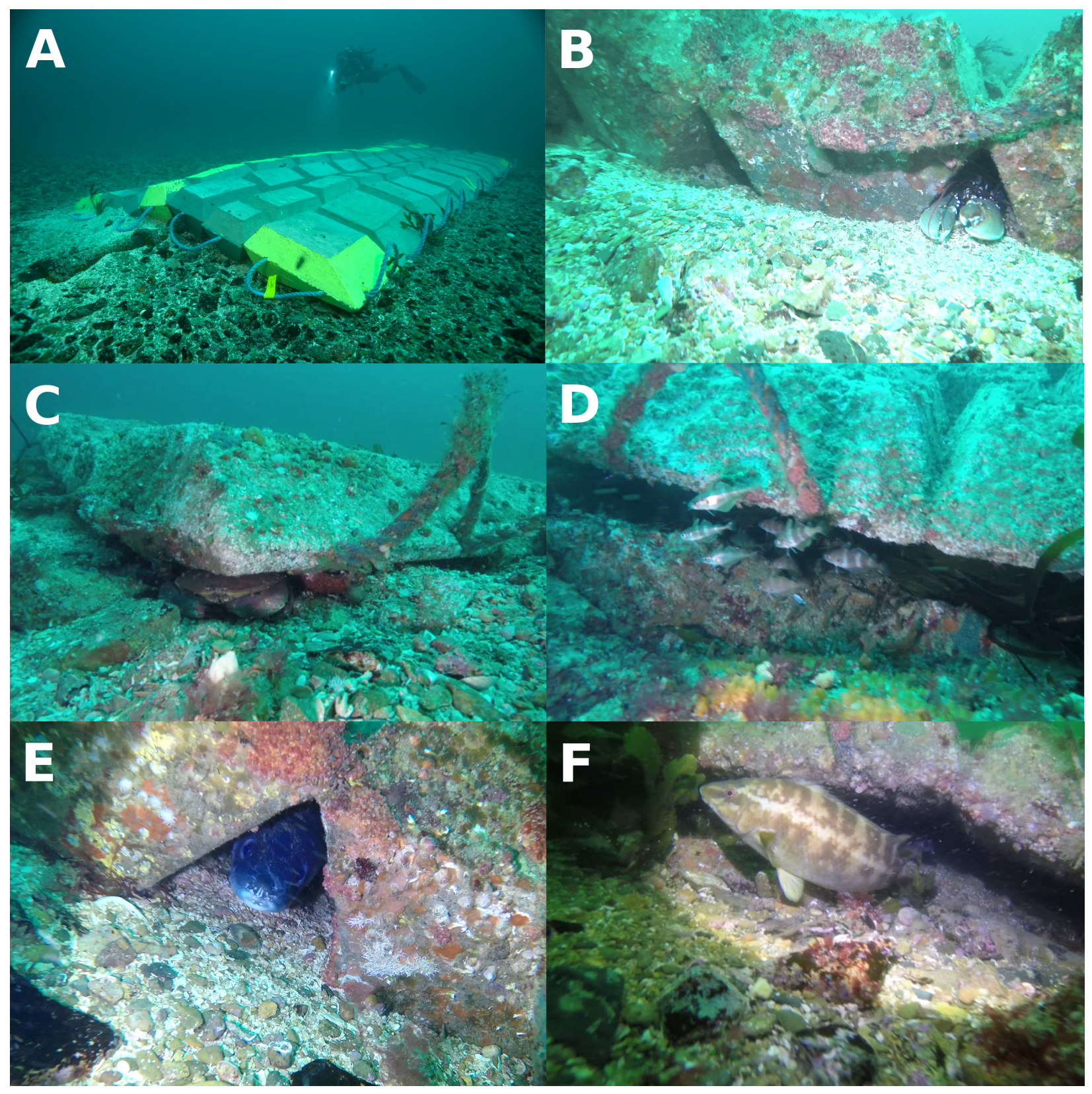




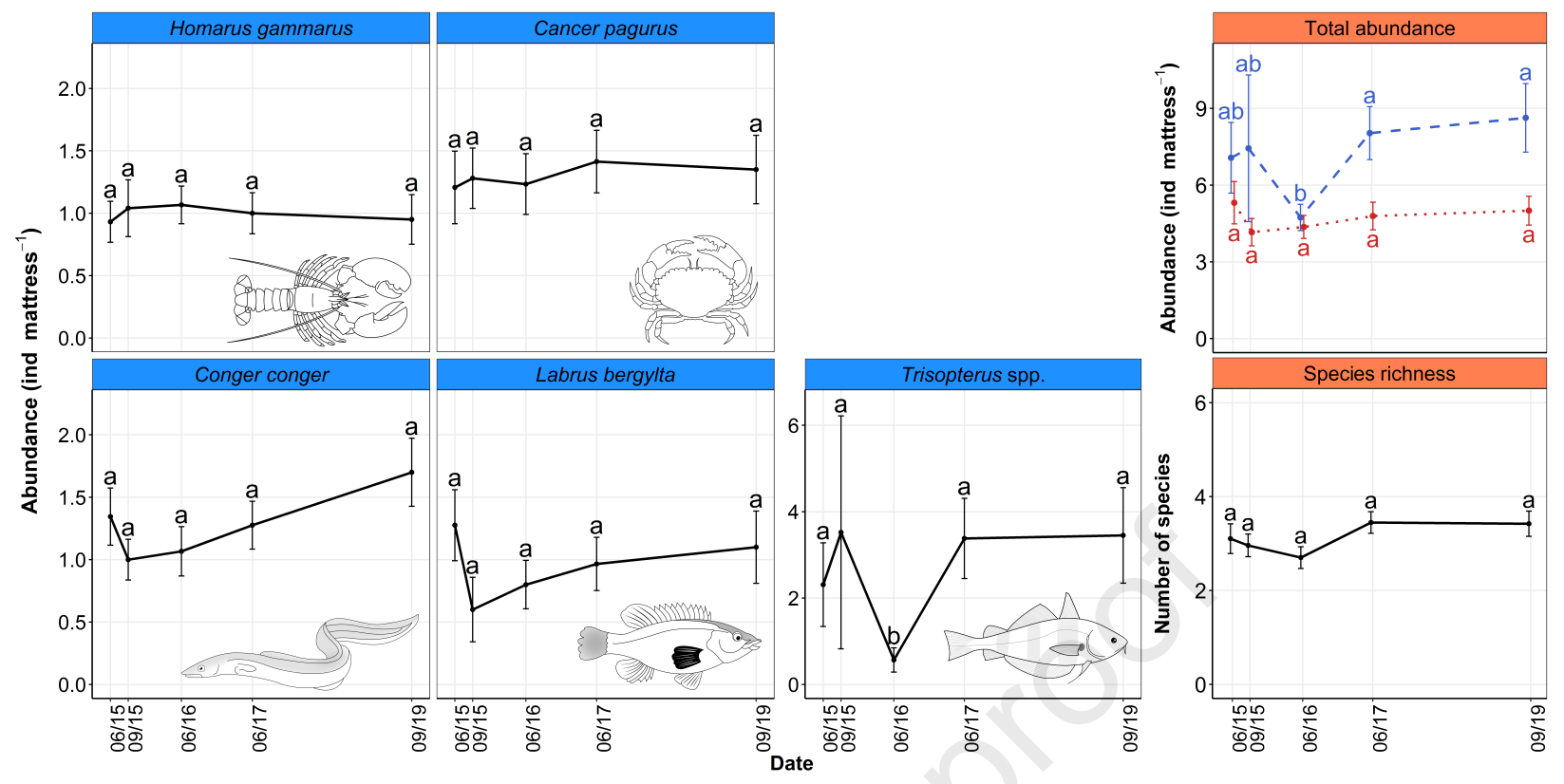




\section{Highlights :}

- The colonisation of artificial structures by benthic megafauna was surveyed during 5 years

- Target taxa showed a constant occupancy of the artificial structures

- Shape and number of shelters largely determine potential for colonisation

- Local physical characteristics significantly impact amount and type of shelters

- It is essential to consider both design of structures and interactions with environment 


\section{Declaration of interests}

$\bigotimes$ The authors declare that they have no known competing financial interests or personal relationships that could have appeared to influence the work reported in this paper.

$\square$ The authors declare the following financial interests/personal relationships which may be considered as potential competing interests:

\section{$30 / 04 / 2020$}

Bastien Taormina

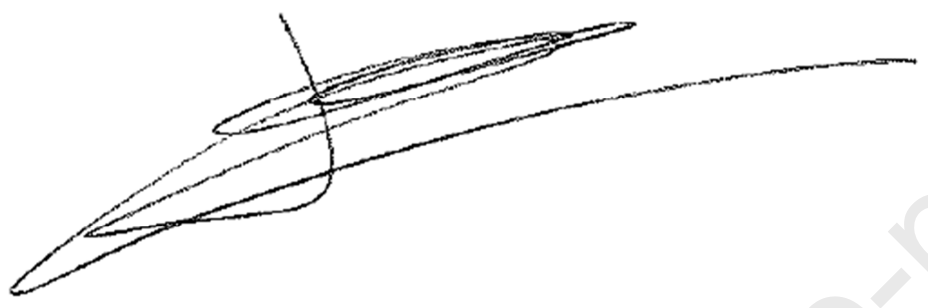

